\title{
Formulation and Assessment of a Wash-Primer Containing Lanthanum "Tannate" for Steel Temporary Protection
}

\author{
Oriana D'Alessandro, Gonzalo J. Selmi, Cecilia Deyá, Alejandro Di Sarli, and Roberto Romagnoli
}

\author{
(Submitted December 5, 2016; in revised form October 13, 2017; published online December 22, 2017)
}

\begin{abstract}
Tannins are polyphenols synthesized by plants and useful for the coating industry as corrosion inhibitors. In addition, lanthanum salts have a great inhibitory effect on steel corrosion. The aim of this study was to obtain lanthanum "tannate" with adequate solubility to be incorporated as the corrosion inhibitor in a wash-primer. The "tannate" was obtained from commercial "Quebracho" tannin and $\left.0.1 \mathrm{M} \mathrm{La}^{\mathrm{L}} \mathrm{NO}_{3}\right)_{3}$. The soluble tannin was determined by the Folin-Denis reagent, while the concentration of Lanthanum was obtained by a gravimetric procedure. The protective action of "tannate" on SAE 1010 steel was evaluated by linear polarization curves and corrosion potential measurements. Lanthanum "tannate" was incorporated in a wash-primer formulation and tested by corrosion potential and ionic resistance measurements. The corrosion rate was also determined by the polarization resistance technique. Besides, the primer was incorporated in an alkyd paint system and its anticorrosion performance assessed in the salt spray cabinet and by electrochemical impedance spectroscopy. Results showed that lanthanum "tannate" primer inhibits the development of deleterious iron oxyhydroxides on the steel substrate and incorporated into a paint system had a similar behavior to the primer formulated with zinc tetroxychromate.
\end{abstract}

Keywords coatings and paints, corrosion, electrochemical impedance spectroscopy, lanthanum, tannins

\section{Introduction}

The original concept of temporary protective coatings has been codified in BS 1133:1966 (Section 6) (Ref 1). This standard is a packaging one concerned with the protection of machinery, components and hardware while "in transit" to customer or while in storage during assembly. The standard recognizes ten cases but, taking into account the manner of application and removal, five main types may be identified: (a) lacquers and organic films, (b) rust-preventatives oils and waxes, (c) anti-fretting oils, (d) vapor-phase inhibitors and, (e) conversion coatings. The first four are removable, and the last is permanent, and may be regarded as a pre-treatment for a later coating system (Ref 1-3).

A wash-primer is a kind of conversion coating which may generate an organic coating when a film forming material is incorporated into the formulation (Ref 4-7). A traditional washprimer is formulated with zinc tetroxychromate (ZTC) as the inhibitor, phosphoric acid to phosphatize the metal surface and

Oriana D'Alessandro, Roberto Romagnoli, and Alejandro Di Sarli, CIDEPINT-CICPBA-CONICET, Av. 52 e/121 y 122, La Plata, Buenos Aires, Argentina and Facultad de Ciencias Exactas, Universidad Nacional de La Plata, La Plata, Argentina; Gonzalo J. Selmi, CIDEPINT-CICPBA-CONICET, Av. 52 e/121 y 122, La Plata, Buenos Aires, Argentina; and Cecilia Deyá, CIDEPINT-CICPBACONICET, Av. 52 e/121 y 122, La Plata, Buenos Aires, Argentina and Facultad de Ingeniería Universidad Nacional de La Plata, La Plata, Argentina. Contact e-mail: c.deya@cidepint.gov.ar.

polyvinylbutiral as the film forming material. This primer proved to be efficient in protecting steel against corrosion (Ref $8)$. The main drawback with this formulation is concerned with the presence of chromate in the primer formula (Ref 9). According to modern trends, it will be desirable to replace ZTC by a more eco-friendly corrosion inhibitor.

Many other inhibitors were proposed to replace chromates, among them, phosphates constitute the most numerous group (Ref 10-14). Intrinsically conducting polymers proved to be as efficient as chromates and phosphates, and they could be synthesized at the nanoscale (Ref 15, 16). More recently, natural and synthetic reservoirs were employed to be loaded with different inhibitors. In this sense, the employment of halloysites and mesoporous silica nanocontainers for powder coatings was reported (Ref 17,18 ). Layered double hydroxides and hydrotalcites were designed to contain organic inhibitors and/or inorganic anions like tungstates, vanadates, etc. (Ref 19, 20). Other miscellaneous reservoirs like cellulose nanofibers (Ref 21) and layer by layer assembled $\mathrm{ZnO}$ nanocontainers filled with benzotriazole (Ref 22) were prepared.

Tannic acid, tannins and related compounds (ellagic acid, gallic acid, etc.) were also found to inhibit steel corrosion (Ref 23-25) with efficiency higher than $85 \%$ (Ref 26). The presence of gallic acid enhanced tannin inhibitive properties (Ref 27). The protective layer generated by tannins was mainly composed of a kind of ferric "tannate," an insoluble dark blue compound, which may act as an electrical insulator between anodic and cathodic sites (Ref 28-30). The formation of the ferric "tannate" film depends on the $\mathrm{pH}$ of the solution, and it was considered that it begins at $\mathrm{pH}=3$ (Ref 29, 31-33). A correlation between the phenolic profile of the tannin and its inhibitive properties was reported (Ref 34).

Several types of tannins, from different trees, were employed in anticorrosion technology. The most widespread ones were extracted from the following plants: mimosa (Ref 24, 
$32,35)$, chestnut (Ref 36, 37), pine (Ref 38), "quebracho" (Ref $25,26,28)$, mangrove (Ref 39,40$)$, etc. As the exploitation of woods and forests continues, new sources of tannin are being encountered (Ref 41, 42).

The degree of protection afforded by tannins is affected by the presence of chlorides on the metal surface. An increase in the surface concentration of chlorides rendered the metal surface more active. No passivation can be found for chloride concentrations higher than $500 \mathrm{mg} \mathrm{m}^{-2}$ (Ref 43).

Particularly, tannins were extensively used in different wash-primers' formulations to generate conversion coatings, principally on steel substrates. Many commercial formulations were available from the 80' (Ref 43-46). As a general rule, these rust converters did not show exceptional protective properties and, when applied on rusted surfaces, they did not match the anticorrosion performance of a conventional primer (Ref 44-47). Rust converters applied on marginally prepared substrates were reported to transform the oxide layer into a kind of magnetite with different stoichiometry than the natural one. Mössbauer parameters of this oxide were found to have intermediate values between natural magnetite and ferric oxide (Ref 46).

Results obtained with the use of tannins are controversial although, as a general rule, when applied on corroded substrates they improve the corrosion behavior of the coating system (Ref $33,34,48)$.

Tannin derivatives such as "tannates" are being employed in anticorrosion paint technology with promising results (Ref 49-51). Recently, Flores and co-workers begun to employ zinc "tannates," obtained from tara tannin, to formulate washprimers and anticorrosion coatings. These "tannates" showed a similar anticorrosion behavior to chromates (Ref 52, 53).

The object of this research was to develop an ecological wash-primer by replacing the toxic and carcinogenic ZTC by more environment friendly inhibitors. In this case lanthanum "tannate" (LT), synthesized in the laboratory from "quebracho" tannin (QT, Schinopsis sp.) and lanthanum salts. Lanthanum compounds are referred to as effective cathodic inhibitors for a great number of metals (Ref 54-56). Different strategies were proposed in order to incorporate this passivating cation in a great variety of coatings (Ref 57-60). In this paper, lanthanum ions were immobilized by tannin macromolecules. The presence of tannins enhanced the formation of a protective film over the metal surface (Ref 61). The anticorrosion performance of LT and that of formulated wash-primer were assessed by electrochemical techniques. Finally, the washprimer was incorporated into a painting scheme and its behavior evaluated by electrochemical impedance spectroscopy (EIS) together with accelerated assays (salt spray and humidity chambers). Results showed that LT anticorrosion efficiency was $\sim 94 \%$. The wash-primer pigmented with LT behaved satisfactorily in accelerated and electrochemical tests.

\section{Materials and Methods}

\subsection{Pigment Preparation and Characterization}

The solution of QT to carry out the experiment was prepared as follows: $60.0 \mathrm{~g}$ of tannin was placed in a $1000 \mathrm{~mL}$ beaker and suspended in $600 \mathrm{~mL}$ of hot deionized water $\left(90^{\circ} \mathrm{C}\right)$, with continuous stirring. Then, $300 \mathrm{~mL}$ of $1 \mathrm{M} \mathrm{KNO}_{3}$ was added to coagulate colloidal materials and the system was left to stand for $24 \mathrm{~h}$, filtered and transferred to a 1000-mL volumetric flask. An aliquot of $50 \mathrm{~mL}$ of the as-prepared tannin solution was placed in a $250-\mathrm{mL}$ beaker, and increasing volumes of $0.1 \mathrm{M} \mathrm{La}\left(\mathrm{NO}_{3}\right)_{3}$ were added to precipitate LT. The precipitation was carried out at two different $\mathrm{pH}$ values: 4.0 and 8.0. After $24 \mathrm{~h}$, the $\mathrm{pH}$ was controlled and adjusted to the corresponding specified values. Finally, the suspension was filtered and the precipitated mass of LT was determined by drying at $100 \pm 5{ }^{\circ} \mathrm{C}$ until constant weight. The mass of $\mathrm{La}$ (III) was obtained by calcination of the LT precipitated, at $900{ }^{\circ} \mathrm{C}$, until constant weight. The residue after calcination was $\mathrm{La}(\mathrm{OH})_{3}$. The mass of precipitated tannin was the difference between both values.

The solubility of the as synthesized LT was determined by dosing the content of tannin in the saturated solution by the Folin-Denis method (Ref 62-64). The Folin-Denis' method is used for analyzing total polyphenols present in tannins solutions. Folin-Denis' reagent was prepared by dissolving $10.0 \mathrm{~g}$ of sodium tungstate $\left(\mathrm{Na}_{2} \mathrm{WO}_{4} \cdot 2 \mathrm{H}_{2} \mathrm{O}\right), 2.0 \mathrm{~g}$ of phosphomolybdic acid $\left(\mathrm{H}_{3} \mathrm{P}\left(\mathrm{MoO}_{10}\right)_{4} \cdot \mathrm{H}_{2} \mathrm{O}\right)$ and $5.0 \mathrm{~mL} \mathrm{H}_{3} \mathrm{PO}_{4}$ in $80 \mathrm{~mL}$ of deionized water, at the boiling temperature. After cooling, the final volume was adjusted to $100 \mathrm{~mL}$. Tannic acid was used as the standard for polyphenols. Standard solutions of tannic acid, containing 1.0, 2.0, 4.0, 5.0, 6.0, 7.0 and $10.0 \mathrm{ppm}$, were prepared from a stock solution. The tannic acid solution was mixed with $2.0 \mathrm{~mL}$ of saturated $\mathrm{Na}_{2} \mathrm{CO}_{3}$ solution and $2.0 \mathrm{~mL}$ of the Folin-Denis' reagent; then, the final volume was adjusted to $25 \mathrm{~mL}$ with distilled water. The reaction was completed after $15 \mathrm{~min}$, and spectrophotometric measurements were performed at $750 \mathrm{~nm}$.

The concentration of $\mathrm{La}$ (III) was also determined by precipitation with $0.1 \mathrm{~N}$ sodium oxalate and further calcination at $900{ }^{\circ} \mathrm{C}$ to obtain a precipitate of lanthanum oxide.

Corrosion potential (Ecorr) and corrosion rate (Icorr) determinations were carried out in order to assess the inhibitive properties of LT. The corrosion potential of a SAE 1010 steel electrode was monitored, as a function of time, in the LT suspensions. The supporting electrolyte was $0.025 \mathrm{M}$ sodium chloride $(\mathrm{NaCl})$. A saturated calomel electrode ( $\mathrm{SCE}$ ) was used as reference.

Corrosion rates (Icorr) were determined by the polarization resistance technique (Ref 65, 66) employing the PotentiostatGalvanostat EG\&G PAR Model and a conventional three electrode cell. The working electrode was a SAE 1010 steel rod (area: $0.28 \mathrm{~cm}^{2}$ ), the reference was the SCE, and the counterelectrode was a Pt mesh. The supporting electrolyte was $0.1 \mathrm{M}$ $\mathrm{NaCl}$ to improve cell conductivity. The sweep amplitude was $\pm 20 \mathrm{mV}$ o.c. and the scan rate $0.166 \mathrm{mVs}^{-1}$.

The inhibitive efficiency was calculated with the equation

$$
\begin{gathered}
E=\frac{I_{0}-I}{I_{0}} \times 100 \quad I_{0}=I \text { corr for the blank; } \\
I=I \text { corr for the sample }
\end{gathered}
$$

Duplicate electrochemical measurements were carried out in normally aerated stirred solutions $(300 \mathrm{rpm})$. The behavior of the steel electrode in QT suspensions was also studied.

\subsection{Wash-Primer Preparation and Characterization}

The wash-primer was prepared on the basis of a tetroxychromate formulation reported elsewhere (Ref 67) which consisted of two different parts, $\mathrm{A}$ and $\mathrm{B}$. The active 
components of the primer were ZTC and phosphoric acid. The pigments and the film forming material, the polyvinylbutiral resin (Ref 68), were contained in part A. Phosphoric acid and the solvents constitute part B. The volume fraction of ZTC was replaced by LT to formulate the alternative wash-primer. Phosphoric acid was replaced by citric acid just to avoid the precipitation of the very insoluble lanthanum phosphate. The composition of part A was given by volume because the properties of the coatings are normally related to the pigment volume concentration (PVC) and its relationship with the critical pigment volume concentration (CPVC) (Ref 69, 70). The final composition of both parts of the primer could be seen in Table 1. Part A was elaborated by dispersing the pigments in a ball mill for $24 \mathrm{~h}$ to achieve an acceptable dispersing degree. Part B was obtained by simply mixing the solvents and citric acid. Other primers formulations were obtained by substituting LT either by QT or by talc; this last one was used as a control. Prior to painting, sandblasted SAE 1010 steel panels were degreased with toluene and the primers were applied by brushing, to match a final dry film thickness of $7 \pm 2 \mu \mathrm{m}$. The panels were allowed to stand for 7 days before testing.

The anticorrosion performance of the different wash-primers was assessed by electrochemical techniques: corrosion potential and ionic resistance variations were monitored as a function of time.

The electrochemical cells employed to evaluate the primed panels were constructed by delimiting $3 \mathrm{~cm}^{2}$ circular zones on the painted surfaces. An acrylic tube $(5.0 \mathrm{~cm}$ high) was placed on the specimen and filled with $0.1 \mathrm{M}$ sodium chloride. The resistance between the coated steel and a platinum electrode was measured employing an ATI Orion (model 170) conductivity meter at $1000 \mathrm{~Hz}$.

The corrosion rate of primed steel was also determined following the procedures described in a preceding paragraph. The determination of corrosion rates by the linear polarization method was possible due to the low ionic resistance of the primers (Ref 71).

Primed steel panels were submerged $24 \mathrm{~h}$ in distilled water. After this period, the coating was removed with acetone and the morphology of the protective layer was observed by scanning electron microscopy (SEM) employing a microscope FEI Quanta 200 with tungsten filament. The surface elemental composition of the protective film was obtained with an energy dispersive RX microanalyzer and the EDX detector Apollo 40.

\subsection{The Behavior of the Wash-Primer in a Paint System}

2.3.1 Formulation, Elaboration and Application of Paints. The anticorrosion behavior of the wash-primers was assessed by incorporating them in a complete painting scheme constituted by one of the primers, anticorrosion alkyd paint and a finish alkyd coating. The dry film thickness of each alkyd coat was $35 \mu \mathrm{m}$.

The binder employed to formulate the coatings was a solvent-borne-medium oil alkyd (50\% linseed oil, 30\% ophthalic anhydride, $8 \%$ pentaerythritol and glycerol and $12 \%$ pentaerythritol resinate). The solvent was white spirit. It was decided to check the anticorrosion properties of the primers employing solvent-borne paints because their behavior has been well documented for many years (Ref 72). The PVC/ CPVC relationship for the anticorrosion paint was 0.8 as suggested in previous research ( $\operatorname{Ref} 73,74)$, and its composition is consigned in Table 2. The topcoat formulation may be found in Table 3. All pigments were dispersed $24 \mathrm{~h}$ in the vehicle (resin and solvent), employing a ball mill, to achieve an acceptable dispersion degree.

2.3.2 The Performance of Anticorrosion Paints Systems Through Accelerated Tests. A set of three panels was placed in the salt spray chamber (ASTM B 117) to evaluate the rusting degree (ASTM D 610). Painted panels were evaluated during 120 days; the mean value of the obtained results was reported in this paper.

Failure at the scribe (ASTM D 1654) was evaluated in other set of panels exposed also to the salt spray cabinet until a qualification 8 was attained; in this case after 25 days of testing.

Table 2 Anticorrosion paint composition expressed as percentage by volume

\begin{tabular}{lc}
\hline Components & Percentage \\
\hline Zinc molybdenum phosphate & 6.54 \\
Non-fibrous magnesium silicate & 6.37 \\
Barite & 6.20 \\
Titanium dioxide & 2.55 \\
Alkyd resin & 60.23 \\
Solvent & 18.11 \\
PVC & 42 \\
\hline
\end{tabular}

Table 3 Topcoat paint composition expressed as percentage by volume

\begin{tabular}{lc}
\hline Components & Percentage \\
\hline Titanium dioxide & 10.8 \\
Alkyd resin & 66.2 \\
Solvent & 23.0 \\
PVC & 24.6 \\
\hline
\end{tabular}

Table 1 Wash-primers composition

\begin{tabular}{|c|c|c|c|c|}
\hline Formulationv/v\% & Zinc tetroxyChromate (ZTC) & Quebracho tannin (QT) & Lanthanum "tannate" (LT) & Talc \\
\hline Polyvinylbutiral resin & 8.18 & 8.18 & 8.18 & 8.18 \\
\hline Pigment & 2.21 & 2.21 & 2.21 & 2.68 \\
\hline Talc & 0.47 & 0.47 & 0.47 & \\
\hline Carbon black & 0.05 & 0.05 & 0.05 & 0.05 \\
\hline Butanol & 22.89 & 22.89 & 22.89 & 22.89 \\
\hline Isopropanol & 64.06 & 64.06 & 64.06 & 64.06 \\
\hline Water & 2.14 & 2.14 & 2.14 & 2.14 \\
\hline PVC & 0.22 & 0.22 & 0.22 & 0.22 \\
\hline
\end{tabular}




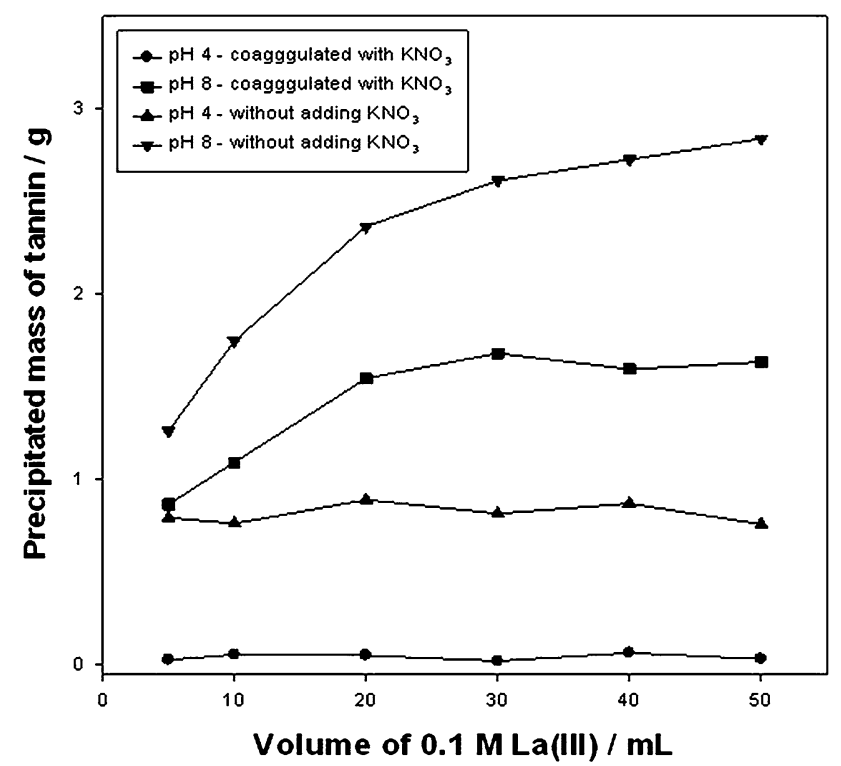

Fig. 1 Mass of tannin precipitated as a function of the volume of $0.1 \mathrm{M} \mathrm{La}\left(\mathrm{NO}_{3}\right)_{3}$ at $\mathrm{pH}=4$ and $\mathrm{pH}=8$

Afterward, they were removed from the chamber, creepage was evaluated, and the panels were finally observed by SEM.

A similar set was placed in the humidity chamber (ASTM D 2247); and blistering degree (ASTM D 714) was also evaluated during 26 days.

Impedance spectra of painted panels (frequency range: $1.10^{-3} \mathrm{~Hz} \leq f \leq 1.10^{5} \mathrm{~Hz}$ ) were performed in the potentiostatic mode, at the Ecorr. Measurements were carried out as a function of the exposure time in $0.5 \mathrm{M} \mathrm{NaCl}$, using the 1255 Solartron FRA and the 1286 Solartron EI. The amplitude of the applied AC voltage was $0.010 \mathrm{~V}$ peak to peak. Two acrylic tubes were attached to each coated panel (working electrode) with an epoxy adhesive. The geometric area exposed to the electrolyte was $15.9 \mathrm{~cm}^{2}$. A large area Pt-Rh mesh of negligible impedance and the SCE were employed as auxiliary and reference electrodes, respectively. This electrochemical experiments were carried out at laboratory temperature $\left(20 \pm 2{ }^{\circ} \mathrm{C}\right)$, using a Faraday cage. Simultaneously, corrosion potential values were recorded as a function of immersion time. The experimental impedance spectra were interpreted on the basis of equivalent electrical circuits using a suitable fitting procedure developed by Boukamp (Ref 75).

\section{Results and Discussion}

\subsection{Pigment Preparation and Characterization}

The mass of tannin precipitated for a given amount of $\mathrm{La}(\mathrm{III})$ was higher at $\mathrm{pH} 8$ than at $\mathrm{pH} 4$ (Fig. 1). At $\mathrm{pH}=4$, the mass of precipitated tannin did not increase significantly as the amount of $\mathrm{La}$ (III) was increased. On the other hand, at $\mathrm{pH}=8$, the mass of tannin in the precipitate increased as the volume of $0.1 \mathrm{M} \mathrm{La}(\mathrm{III})$ increased to finally reach a plateau when $3 \mathrm{mmol}$ of La(III) was added to the tannin suspension. The amount of precipitate increased if the colloidal substances in the tannin dispersion were not previously coagulated with $0.10 \mathrm{M} \mathrm{KNO}_{3}$

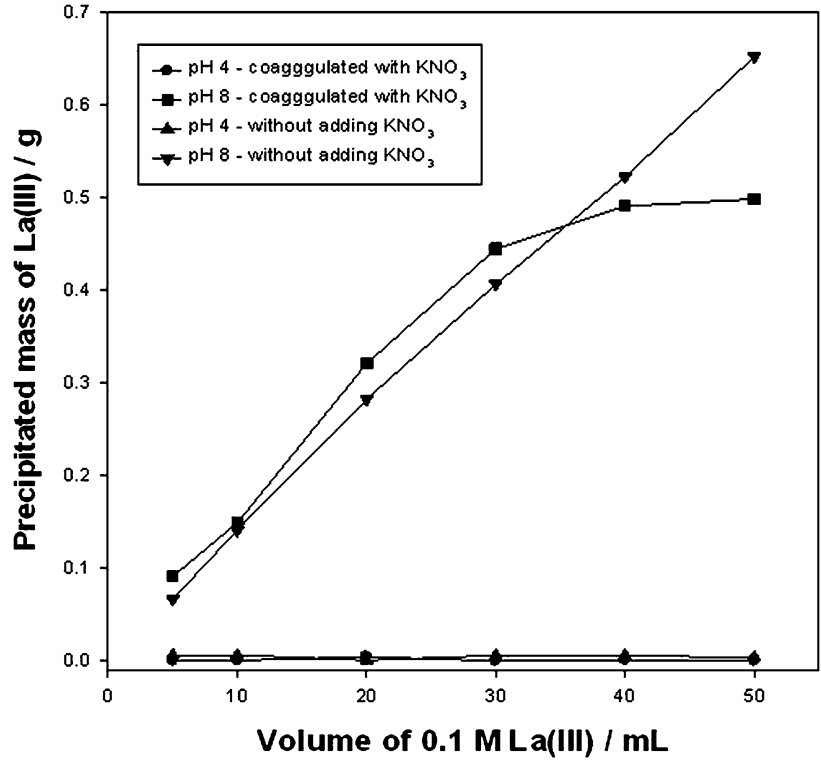

Fig. 2 Mass of lanthanum precipitated as the corresponding oxide

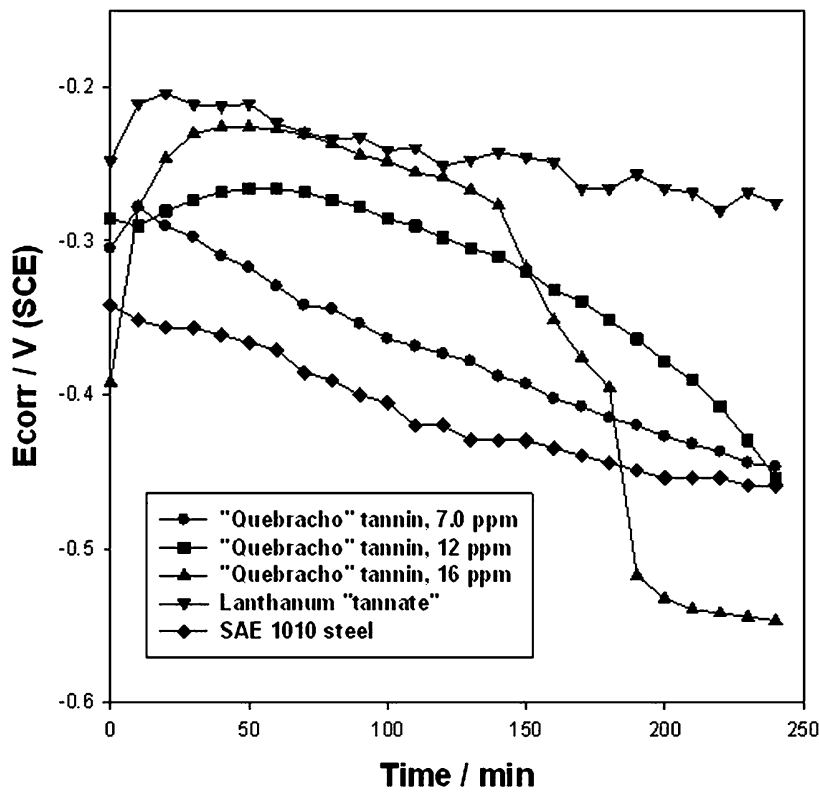

Fig. 3 Steel corrosion potential in pigments suspensions in $0.025 \mathrm{M} \mathrm{NaCl}$

(Fig. 1). The mass of La precipitated together with tannin was very low at $\mathrm{pH}=4$. However, at $\mathrm{pH}=8, \mathrm{La}$ increased as the volume of $0.1 \mathrm{M} \mathrm{La}(\mathrm{III})$ increased. The mass of precipitated $\mathrm{La}$ also reached a plateau when $3 \mathrm{mmol}$ of $\mathrm{La}(\mathrm{III})$ was added to the tannin suspension previously coagulated with $\mathrm{KNO}_{3}$ (Fig. 2). According to these results, it was decided to precipitate LT at $\mathrm{pH}=8$, employing potassium nitrate and a TQ: $\mathrm{La}(\mathrm{III})$ relationship equal to $3.0 \mathrm{~g}$ : $3.0 \mathrm{mmol}$.

The solubility of tannin as determined by the Folin-Denis' reagent was $7.0 \mathrm{ppm}$. La(III) concentration was very low. The oxalate method to determine La content did not yield the formation of any precipitate. As no precipitate was formed, it 
Table 4 SAE 1010 steel corrosion rate in LT suspension in $0.10 \mathrm{M} \mathrm{NaCl}$

SAE 1010 steel corrosion rate, $\mu$ A.cm ${ }^{-2}$

\begin{tabular}{llcccc}
\cline { 2 - 3 } Time, $\mathbf{h}$ & \multicolumn{2}{c}{ Quebracho tannin concentration, ppm } & Lanthanum tannate & Supporting electrolyte \\
\cline { 2 - 4 } & $\mathbf{7}$ & $\mathbf{1 2}$ & $\mathbf{1 6}$ & 7.89 & 152 \\
2 & 22.8 & 10.2 & 33.1 & 6.40 & 138 \\
5 & 19.8 & 11.2 & 29.2 & 5.82 & 101 \\
\hline
\end{tabular}

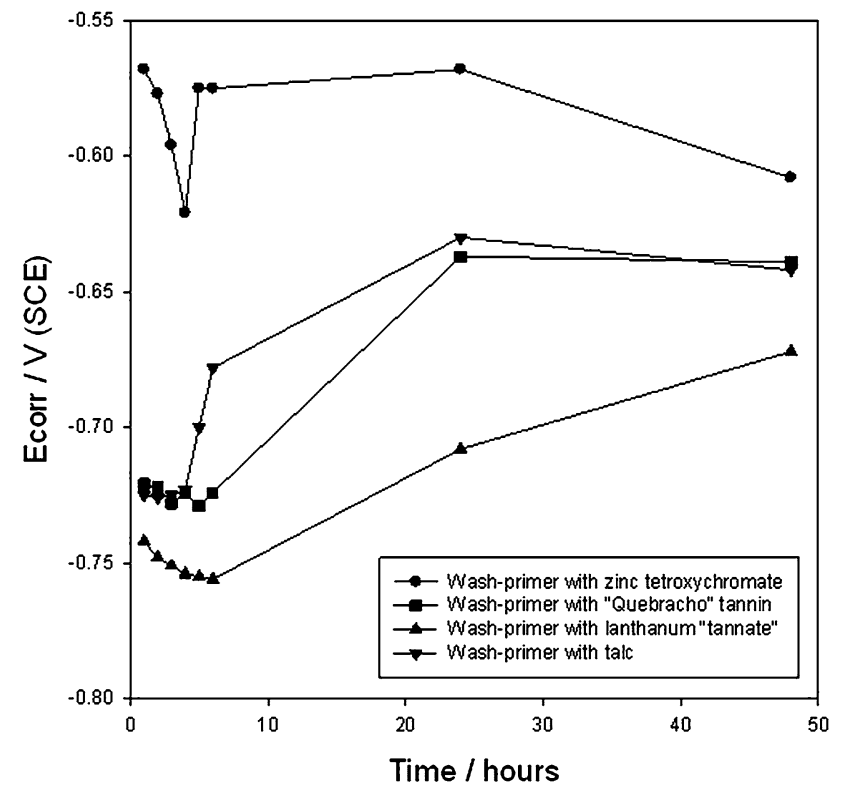

Fig. 4 Corrosion potential of primed panels, as a function of time, in $0.1 \mathrm{M} \mathrm{NaCl}$

was concluded that $\mathrm{La}(\mathrm{III})$ was under the detection limit. However, LT can act as a reservoir of $\mathrm{La}$ (III) which may be released, particularly after the acidification of the anodic sites. La protects steel at very low concentrations (Ref 55).

QT displaced the Ecorr of SAE 1010 steel to more positive values, with respect to the control (SAE 1010 steel in the supporting electrolyte). The displacement was higher as the tannin concentration was increased, but the Ecorr diminished as time elapsed, matching the most negative values in the case of the higher tannin concentration. The highest displacement was achieved with LT suspension and Ecorr maintained fluctuating around $\sim-0.250 \mathrm{~V}$ during the test period. The displacement was higher as time elapsed, and it was, as an average, $0.170 \mathrm{~V}$ (Fig. 3). Evidently, LT was the best inhibitor for steel corrosion.

Preceding results were also confirmed by Icorr determinations (Table 4). Both QT and LT inhibited steel corrosion. For a given QT concentration, steel corrosion rate decreased as time elapsed. Icorr decreased as the concentration of QT increased from 7 to $12 \mathrm{ppm}$, but the most concentrated solution was detrimental to steel protection. Steel corrosion rate was lower in LT suspension and also diminished continuously during $24 \mathrm{~h}$ of exposure. LT reduced significantly steel corrosion rate, being its efficiency $\approx 94 \%$. The anticorrosive efficiency for the "quebracho" tannin was 83,91 and $84 \%$ for 7,12 and 16 ppm solutions, respectively.

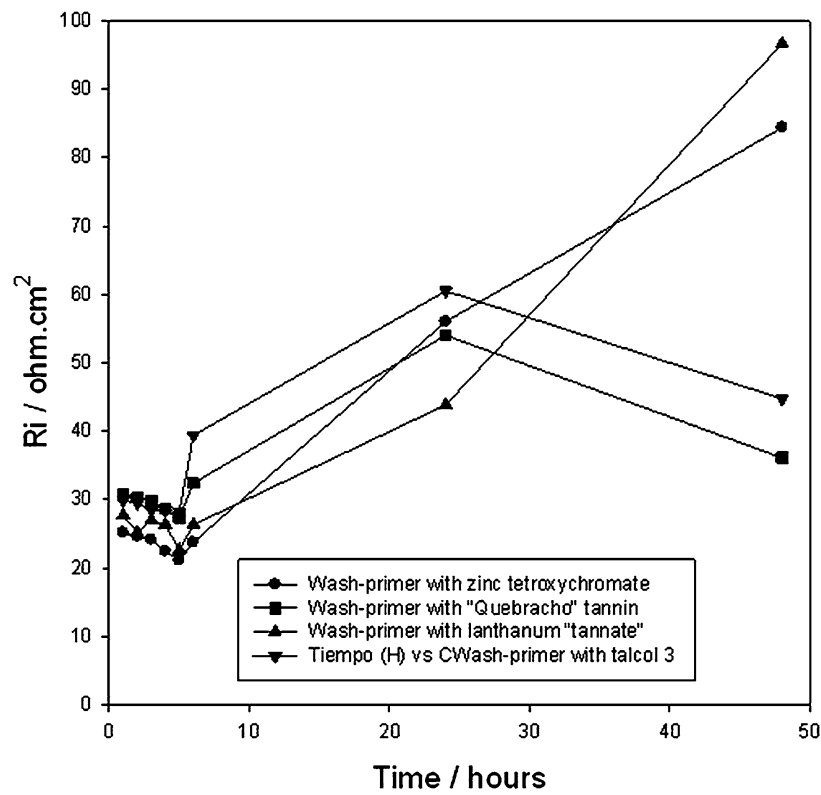

Fig. 5 Ionic resistance of primed panels, as a function of time, in $0.1 \mathrm{M} \mathrm{NaCl}$

\subsection{Wash-Primer Characterization}

The primer formulated with zinc tetroxychromate caused steel Ecorr to be displaced to more positive potentials with respect to the other primers (Fig. 4). The primers containing QT, LT or talc showed, at the beginning of the test period, very negative potentials which seemed to be related to metal dissolution to form a protective film. In the case of tannin compounds iron "tannates" may be formed. This displacement was more noticeable in the case of the primer formulated with LT. As time went on, Ecorr decreased for the chromate primer and increased in the other cases. At the end of the test period measured Ecorr values did not differ significantly. In every case, measured potentials corresponded to the formation of iron oxides (Fig. 4).

As it could be expected, the ionic resistance of every primer was rather low and, as a consequence, the control of the corrosion process was principally kinetic in nature (Ref 76, 77) (Fig. 5). The ionic resistance of the primers containing ZTC and LT increased continuously after the first hours of immersion. The primers formulated with QT and that containing talc exhibited a similar behavior till 1 day of exposure. Then, the ionic resistance dropped off to match a final value which was slightly higher than the initials ones. The increased resistance could be interpreted in terms of pore plugging by corrosion products. 


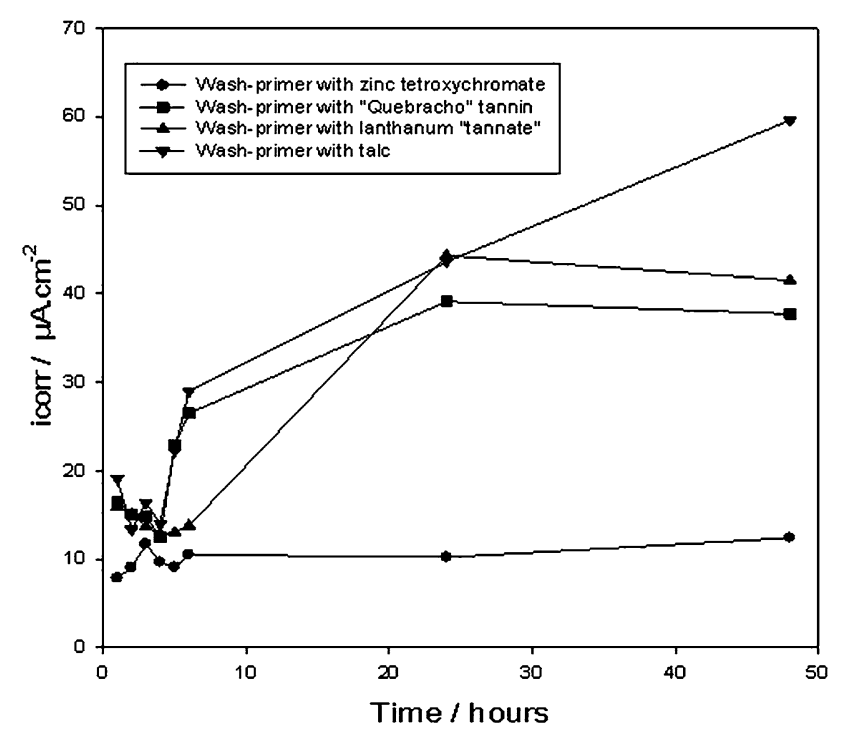

Fig. 6 Corrosion rate of primed panels, as a function of time, in $0.1 \mathrm{M} \mathrm{NaCl}$

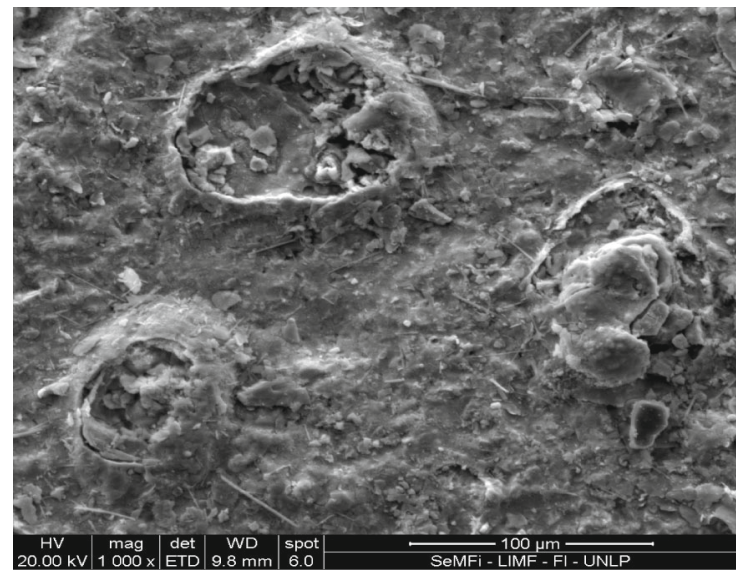

(a) $(1000 \mathrm{X})$

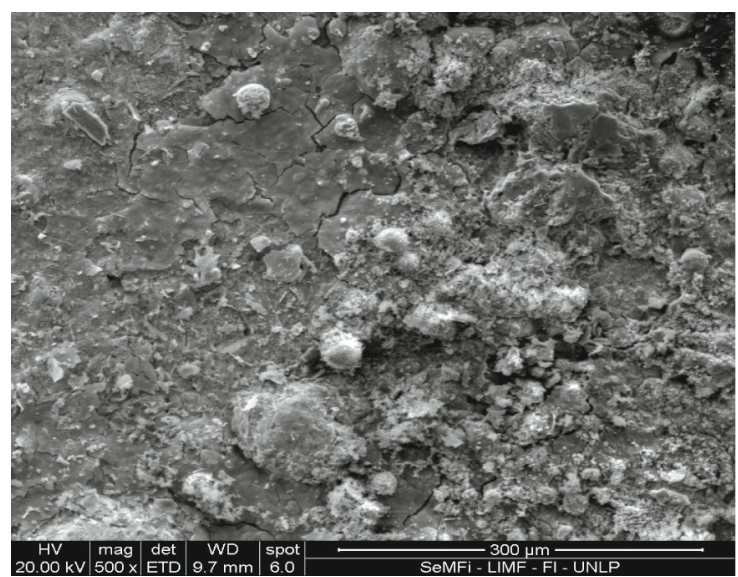

(c) $(500 \mathrm{X})$
The primer formulated with ZTC was effective in reducing steel corrosion rate. Initially, Icorr of the panels coated with the rest of the primers was, at least, double than that of the chromate primer (Fig. 6). After $2 \mathrm{~h}$ of immersion, Icorr of all primed panels did not differ significantly from each other. Icorr of the primer containing talc begun to increase after $4 \mathrm{~h}$ of exposure, while that of the panel coated with the primer containing LT increased after $6 \mathrm{~h}$ of immersion. Differences became greater at the end of the immersion period and the highest corrosion rate corresponded to the primer containing talc.

The protective layer formed beneath the primer, after $24 \mathrm{~h}$ of immersion in distilled water, was observed once the primer was removed with acetone.

The steel surface in contact with the primer containing talc was covered with an oxide layer. Regular amounts of globular oxides were also observed in certain regions of the scanned surface (Fig. 7). The density of these formation increased with the exposure time from 5 (Fig. 7a and b) to $24 \mathrm{~h} \mathrm{(Fig.} \mathrm{7c).}$ After $24 \mathrm{~h}$ coarse oxide formation was also observed (Fig. 7c). The base protective film exhibited cracks and certain "peeling" (Fig. 7b). The film composition was, basically, iron oxyhydroxides with rests of talc.

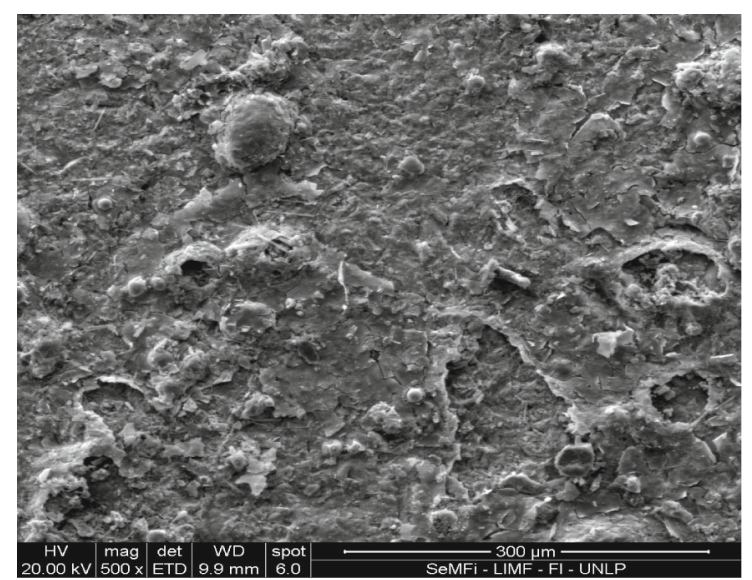

(b) $(500 \mathrm{X})$

Fig. 7 SEM micrographs of the steel surface coated with the primer pigmented with talc. (a) and (b) 5-h exposition, (c) 24-h exposition 


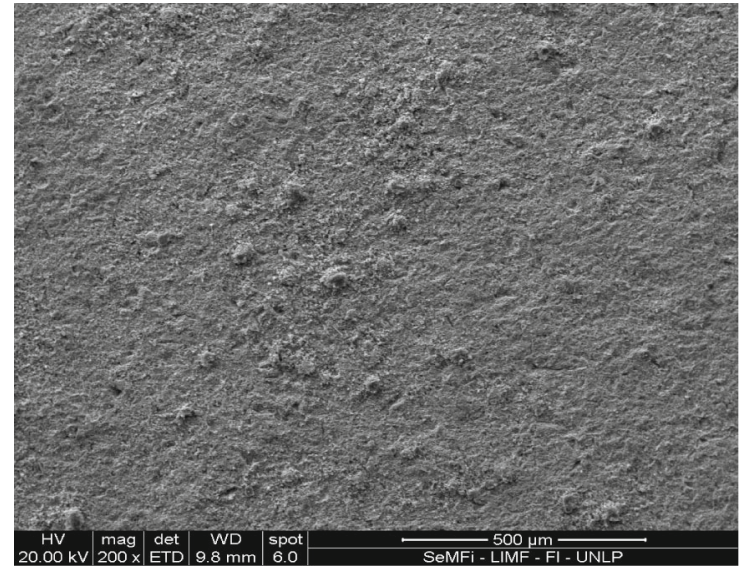

(a) $(200 \mathrm{X})$

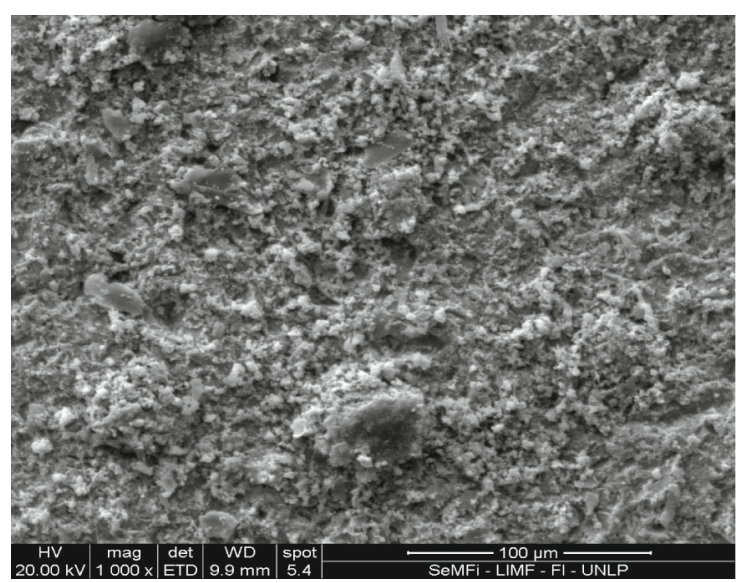

(c) $(1000 \mathrm{X})$

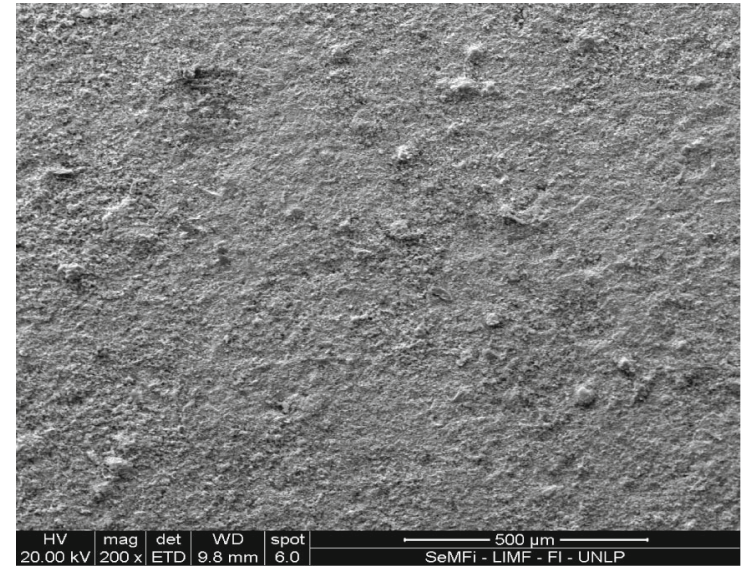

(b) (200X)

Fig. 8 SEM micrographs of the steel surface coated with the primer pigmented with zinc tetroxychromate. (a) 5-h exposition, (b and c) 24-h exposition

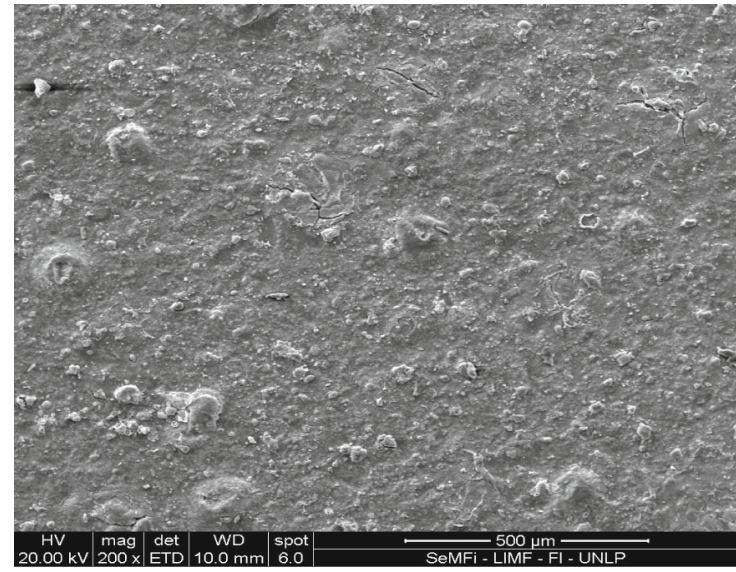

(a) (200X)

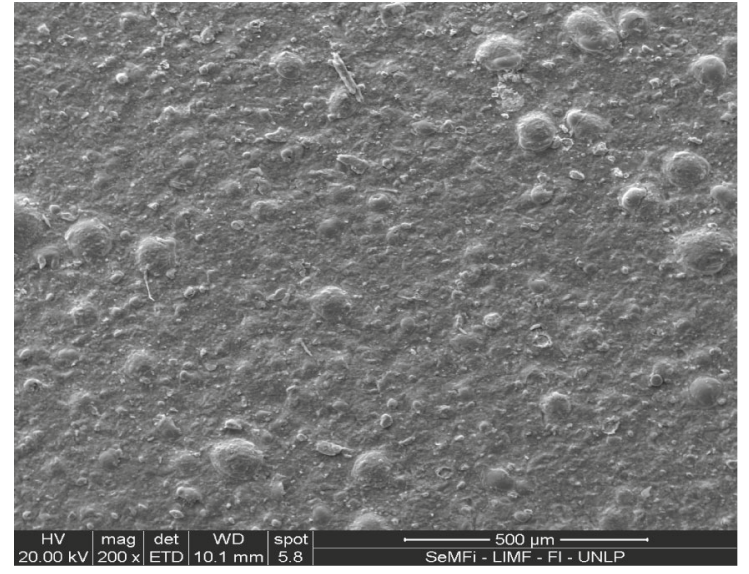

(b) $(200 \mathrm{X})$

Fig. 9 SEM micrographs of the steel surface coated with the primer pigmented with "Quebracho" tannin. (a) 5-h exposition, (b) 24-h exposition 


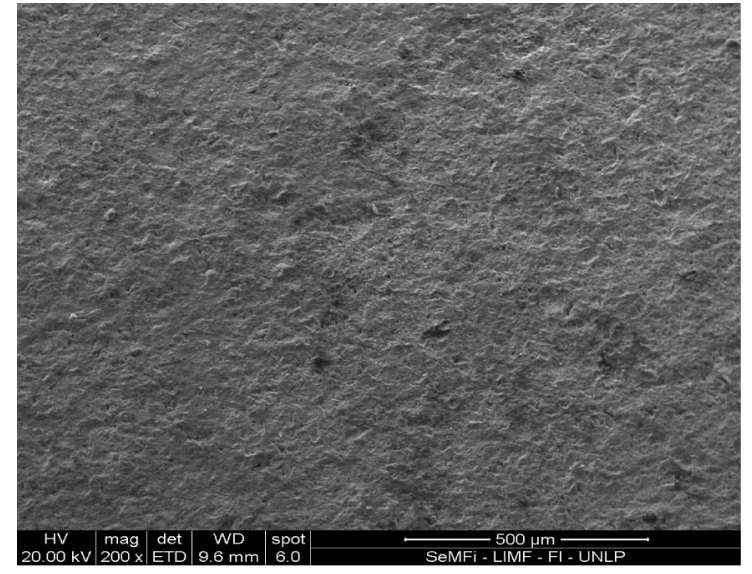

(a) $(200 X)$

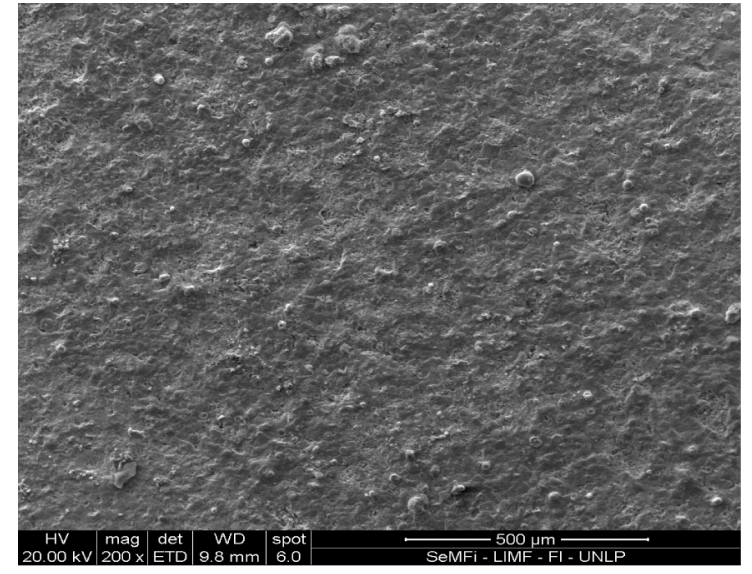

(b) (200X)

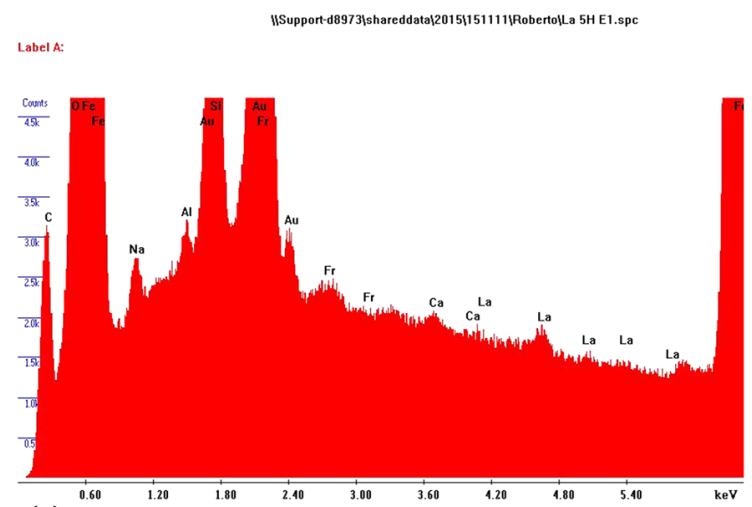

(c)

Fig. 10 SEM micrographs of the steel surface coated with the primer pigmented with lanthanum "tannate." (a) 5-h exposition, (b) 24-h exposition, (c) EDX spectrum of the primed surface after 5-h exposition

The protective layer under the primer with chromate was composed by iron oxyhydroxides. Globular formations were also detected but they were much smaller (Fig. 8a and b). At higher magnifications, it could be seen that they were in the formation process (Fig. 8c). $\mathrm{Cr}(\mathrm{VI})$ and $\mathrm{Zn}$ (II) ions incorporated into the protective film in variable percentages; 0.7 to $1.1 \%$ for $\mathrm{Cr}(\mathrm{VI})$ and higher values, 7.3 to $10.6 \%$, for $\mathrm{Zn}(\mathrm{II})$. It must be kept in mind that both ions may inhibit steel corrosion (Ref 78). QT was not as effective as ZTC on inhibiting steel corrosion (Fig. 9); the development of some globular oxides was detected. The presence of LT in the primer film inhibited the development of these oxides as chromate did (Fig. 10). The presence of LT in the primer generated similar protective films to that of chromate (Fig. 10a and b). The basic composition of the film was iron oxyhydroxides with a relative high $\mathrm{C}$ content $(\sim 9.2 \%)$ due to the presence of the iron "tannate" film. The signal of La was scarcely higher than that of base signal (Fig. 10c).

The primer containing LT as well as that with ZTC protected steel for more than 6 months in a laboratory atmosphere $\left(20 \pm 2{ }^{\circ} \mathrm{C}, 65 \% \mathrm{RH}\right)$.

\subsection{The Behavior of the Wash-Primer in a Paint System}

Results from the salt spray chamber revealed that all washprimers had a similar anticorrosion behavior than that formulated with ZTC, after one month and a half of exposure (Table 5), except the control. The poor behavior of the control panels could be due to the absence of a primer that inhibits corrosion. The presence of the primers extended the useful life of the paint system. 
Table 5 Rusting degree (R) (ASTM D 610) and creepage from the scribe (C) (ASTM D 1654) of painted panels in the salt spray test (ASTM B 117)

\begin{tabular}{|c|c|c|c|c|c|c|c|c|c|}
\hline \multirow[b]{3}{*}{ Wash-primer } & \multicolumn{9}{|c|}{ Time, days } \\
\hline & \multirow{2}{*}{$\begin{array}{l}2 \\
R\end{array}$} & \multirow{2}{*}{$\begin{array}{l}4 \\
\mathrm{R}\end{array}$} & \multicolumn{2}{|c|}{17} & \multicolumn{2}{|c|}{25} & \multirow{2}{*}{$\begin{array}{c}32 \\
\mathbf{R}\end{array}$} & \multirow{2}{*}{$\begin{array}{l}40 \\
R\end{array}$} & \multirow{2}{*}{$\begin{array}{l}45 \\
R\end{array}$} \\
\hline & & & $\mathbf{R}$ & $\mathbf{C}$ & $\mathbf{R}$ & $\mathbf{C}$ & & & \\
\hline Zinc tetroxychromate & 10 & 10 & 10 & 10 & 9P & 9 & $9 \mathrm{P}$ & $9 \mathrm{P}$ & $9 \mathrm{P}$ \\
\hline Quebracho "tannin" & 10 & 9P & $9 \mathrm{P}$ & 10 & 9P & 8 & $9 \mathrm{P}$ & 9P & 9P \\
\hline Lanthanum "tannate" & 10 & 9P & $9 \mathrm{P}$ & 10 & $9 \mathrm{P}$ & 9 & $9 \mathrm{P}$ & $9 \mathrm{P}$ & 9P \\
\hline Talc & 10 & $9 \mathrm{~S}$ & $9 \mathrm{~S}$ & 10 & $9 \mathrm{~S}$ & 9 & $9 \mathrm{P}$ & $9 \mathrm{P}$ & 9P \\
\hline Control & 10 & $9 \mathrm{~S}$ & $9 \mathrm{~S}$ & 9 & $9 \mathrm{~S}$ & 8 & $8 \mathrm{P}$ & $7 \mathrm{G}$ & $6 \mathrm{G}$ \\
\hline
\end{tabular}

\section{R: Rusting degree (ASTM D 610)}

\begin{tabular}{lllllllll}
\hline Rusting degree & 10 & 9 & 8 & 7 & 6 & 5 & 4 & 3 \\
$\%$ rusted area & No rust & 0.03 & 0.1 & 0.3 & 1 & 3 & 10 & 16 \\
\hline
\end{tabular}

C: Mean creepage from the scribe (ASTM D 1654)

\begin{tabular}{llll}
\hline Rating number & 10 & 9 & 7 \\
$\mathrm{~mm}$ & 0 & Over $0-0.5$ & Over $0.5-1.0$ \\
\hline
\end{tabular}

$S$ spot (the bulk of the rusting is concentrated in a few localizes areas); $G$ general (various size rust spots are randomly distributed across the surface); $P$ pinpoint (the rust is distributed across the surface as very small individual speaks of rust)

At longer exposure time, the panels with the primer pigmented with talc must be taken off the chamber after 50 days of exposure (qualification $5 \mathrm{G}$ ). The primer formulated with QT almost had a similar performance than ZTC, but failed after 110 days of exposure (qualification 5G). After 120 days of exposure, only the primer containing LT (qualification 8P) performed as that containing ZTC (qualification 9P).

No significant differences were found among creepage for the different paint systems, after 25 days of exposure.

The metal surface coated with the different paint systems and exposed to the salt spray cabinet was examined by SEM after paints removal with suitable solvents.

Figure 11(a) shows ZTC panel after 25 days of exposition, while Fig. 11(b) shows the metal surface under the paint. The metal surface, which was in contact with the chromate primer, presented two different zones. One of them was covered with a corrosion products layer, while the other seemed to be the base metal, free from oxides, after the attack by the acid fraction of the primer (Fig. 11c). Figure 11(d) shows with certain detail the base metal. The protective layer was composed, basically, by iron oxides as it was revealed by the percentage of iron found in it $(69.0 \%)$. $\mathrm{Zn}$ and $\mathrm{Cr}$ from ZTC were also found in the protective layer but in lower proportions (4.5 and $1.3 \%$, respectively). Two different regions were observed in the surroundings of the crosscut (Fig. 11e and f). One of them consisted in an oxide layer of the non-expansive type (Fig. 11e). The Fe content in the film was high (91.6\%), while that of $\mathrm{O}$ was too low $(2.8 \%)$. This fact led to think that the protective film was very thin and the percentage of Fe was highly influenced by the base metal. A small amount of $\mathrm{Cr}$ $(0.17 \%)$ was incorporated into the protective layer. Iron oxides in Fig. 10(f) seemed to be of the expansive type and contained small amounts of $\mathrm{Cl}(0.25 \%)$ and $\mathrm{Cr}(0.24 \%)$.

In the case of the primer formulated with QT, Fig. 12(a) shows the exposed panel, while Fig. 12(b) shows the unpainted exposed panels. The steel surface appeared to be covered with a protective layer (Fig. 12c) which broke in certain areas (Fig. 12d) allowing to see the base metal. The protective layer was composed by iron oxyhydroxides as it could be deduced from the $\mathrm{Fe}(57.6 \%)$ and $\mathrm{O}(11.6 \%)$ contents. The relatively higher content of C $(25.0 \%)$ led to think that iron "tannate" was also formed. In the vicinity of the crosscut, most of the metal surface remained free from oxides and only small areas were covered with iron oxyhydroxides (Fig. 12e). A micrograph of the oxide layer region is included in Fig. 12(f). Figure $12(\mathrm{~g})$ is a view of the steel bare surface and some spots of iron oxide.

The surface under the paint system containing the primer with LT was covered with a porous and continuous film mainly composed by iron oxyhydroxides (Fig. 13a and b). The zone adjacent to the crosscut (Fig. 13c) presented a morphology similar to that of the primer formulated with QT; this is to say, a spot of iron oxyhydroxides, the base metal free from oxides and another spot with $\mathrm{La}$ (1.3\%). The presence of tannins in the primers restrained the formation of an oxide film. 


\section{Author's personal copy}

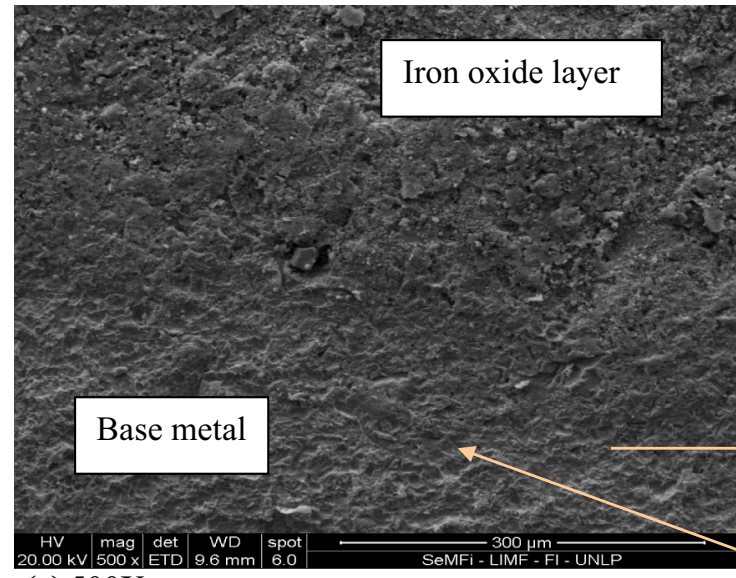

(c) $500 \mathrm{X}$

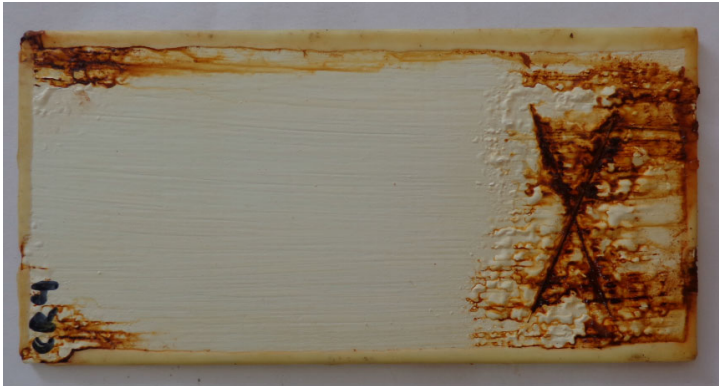

(a) Exposed panel

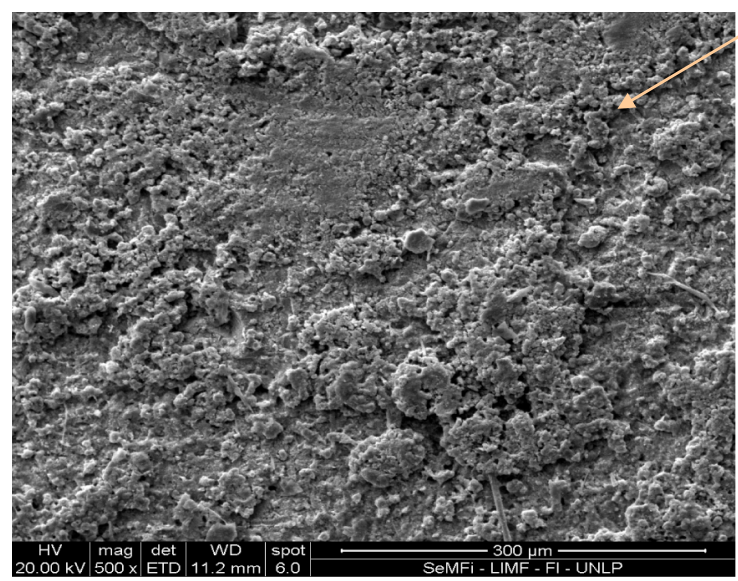

(e) $500 \mathrm{X}$

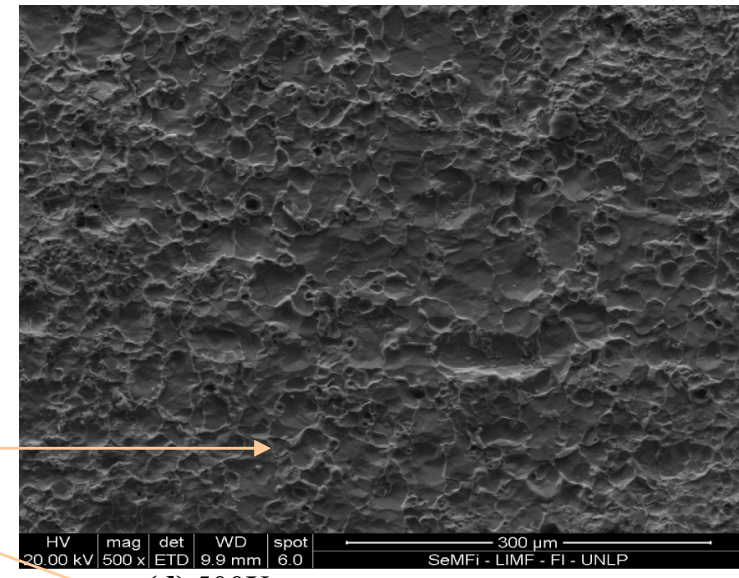

(d) $500 \mathrm{X}$

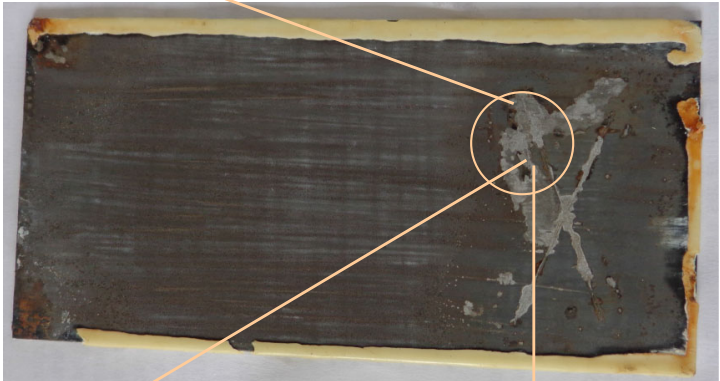

(b) Unpainted panel

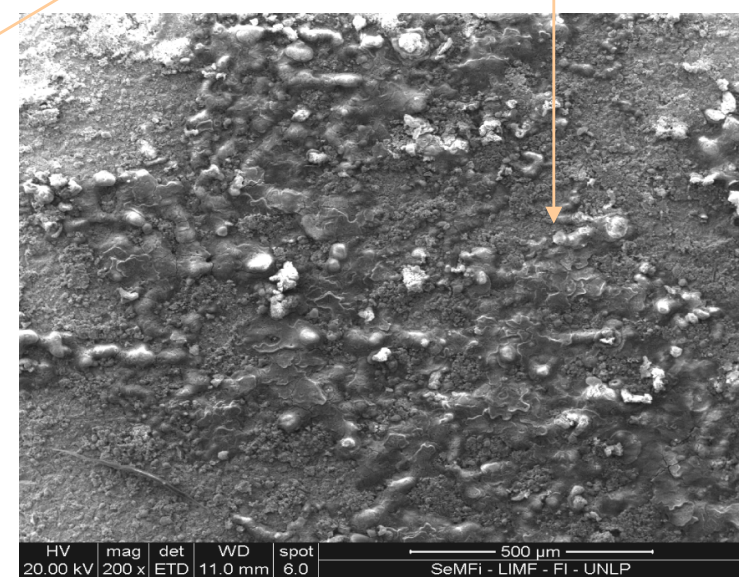

(f) $200 \mathrm{X}$

Fig. 11 SEM micrographs of the steel surface coated with the paint system containing the chromate primer exposed to the salt spray test for 25 days. (a) Exposed panel, (b) unpainted panel; after removal of the alkyd paints (c) far from the crosscut, (d) bare metal surface, (e) and (f) in the crosscut

Blistering in the humidity chamber begun after 15 days of exposure for the primers containing QT and LT; the blistering degree was $6 \mathrm{~F}$ and $8 \mathrm{~F}$, respectively. The controls blistered after 26 days, and the blistering degree was $4 \mathrm{~F}$ in every case. The paint system with the ZTC primer blistered lately, and the degree was $8 \mathrm{~F}$. According to ASTM D714, F means few blisters, while size 8 represents the smallest size seen by unaided eye, while 6, 4 and 2 represent progressively larger sizes.
The analysis of Ecorr variations of painted panels revealed that the paint systems displaced the values to more positive ones. However, within the first week of immersion, Ecorr moved to more negative values, particularly in the case of the systems with the primer formulated with QT and talc (Fig. 14).

Electrochemical impedance spectroscopy proved to be a powerful tool for investigating the metal-coating interface (Ref 79-81). Bode's plots are included in Fig. 15. All paint systems exhibited a capacitive-resistive response except those systems 


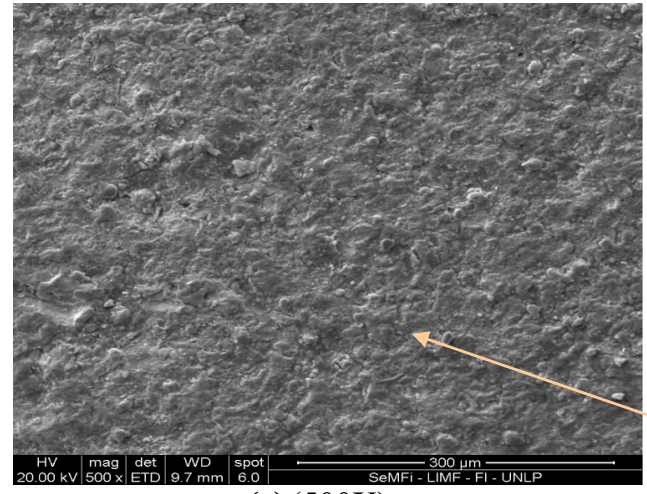

(c) $(500 \mathrm{X})$

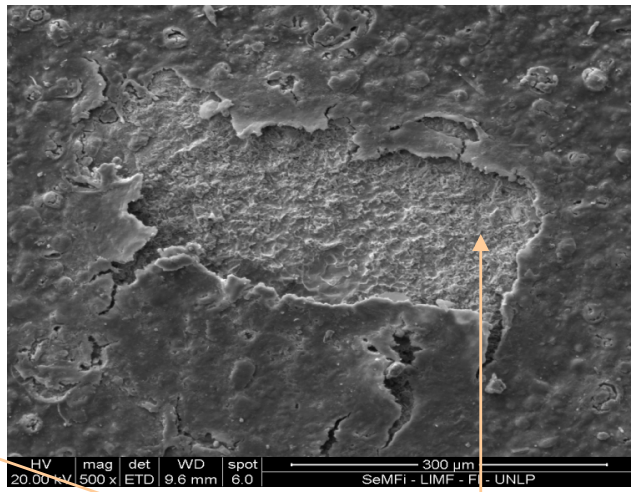

(d) $(500 X)$
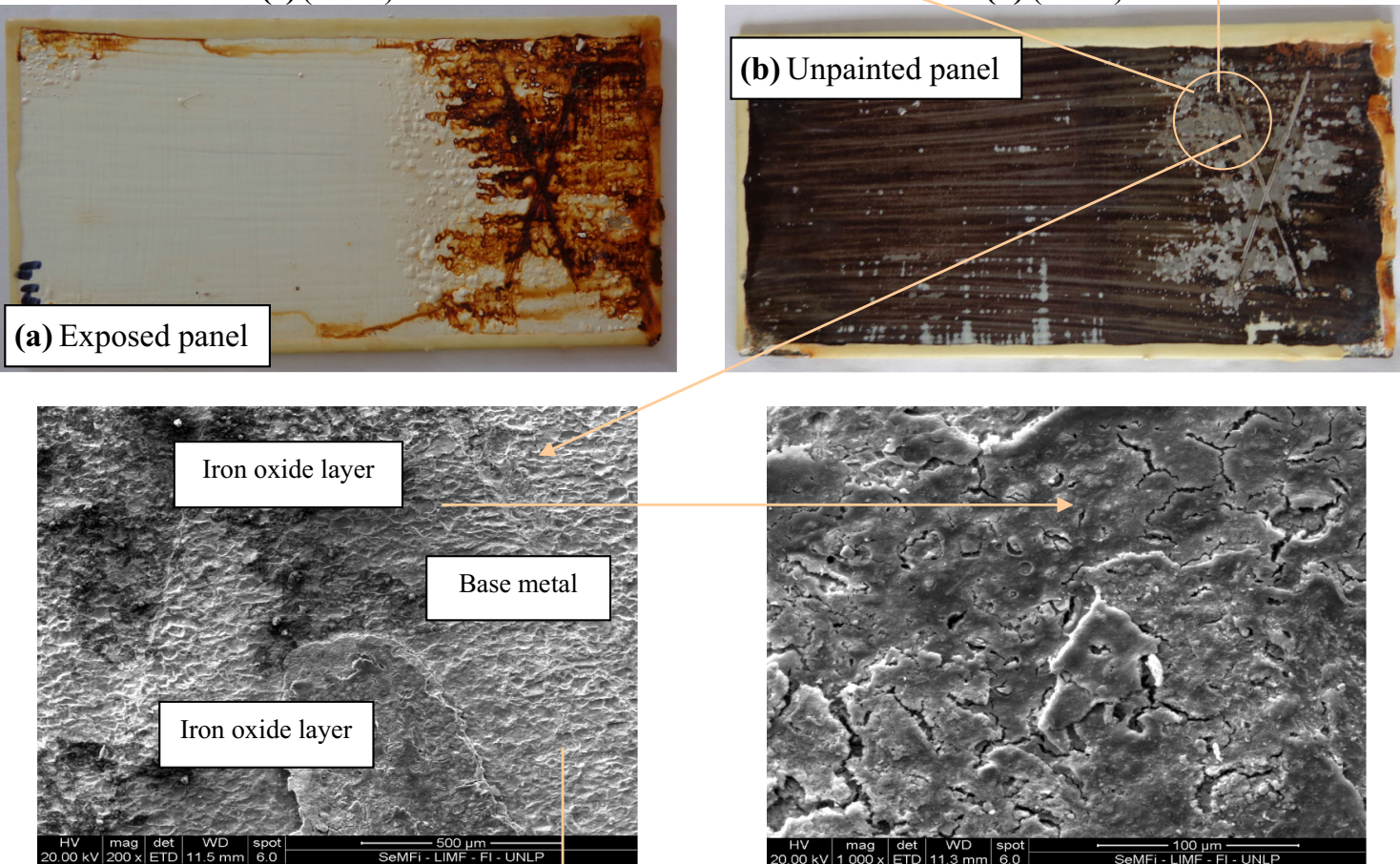

(e) $(200 \mathrm{X})$

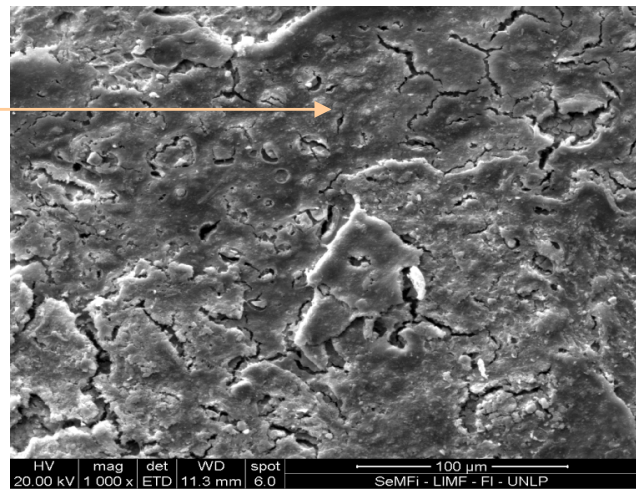

(f) $(1000 \mathrm{X})$

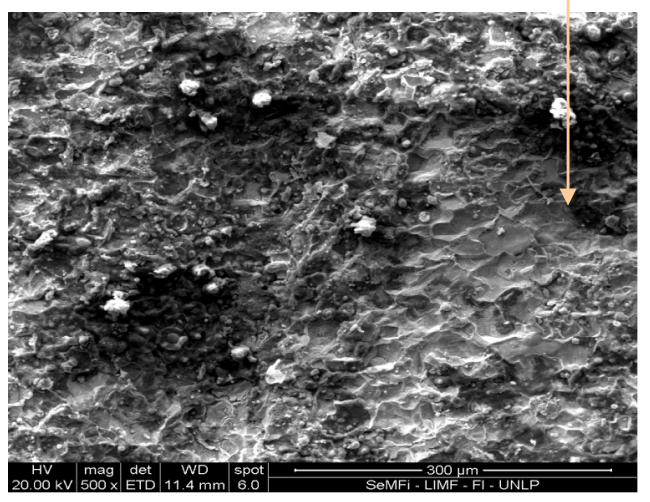

(g) $500 \mathrm{X}$

Fig. 12 SEM micrographs of the steel surface coated with the paint system containing the primer formulated with "Quebracho" tannin exposed to the salt spray test for 25 days. (a) Exposed panel, (b) unpainted panel; after removal of the alkyd paints (c) and (d) far from the crosscut, (eg) adjacent to the crosscut 


\section{Author's personal copy}

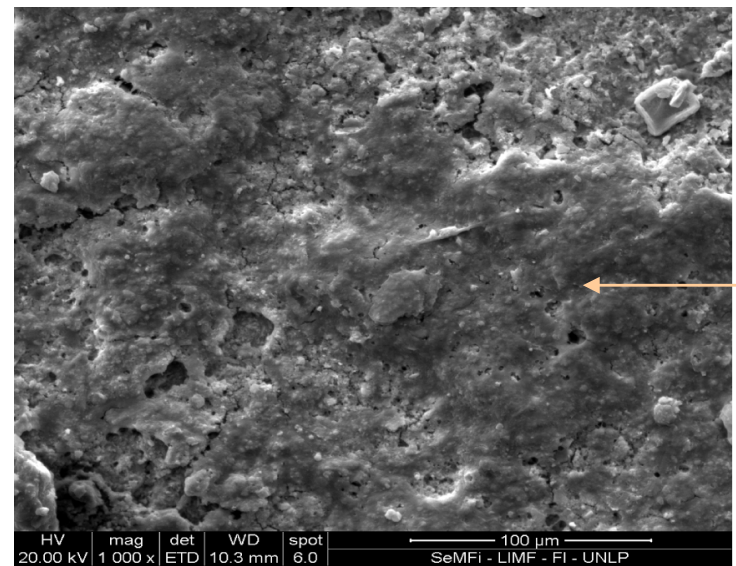

(c) $1000 \mathrm{X}$

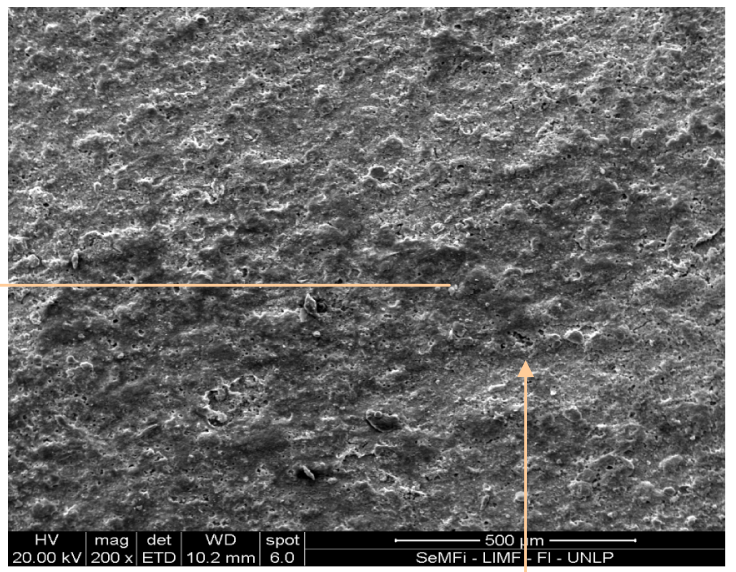

(d) $200 \mathrm{X}$

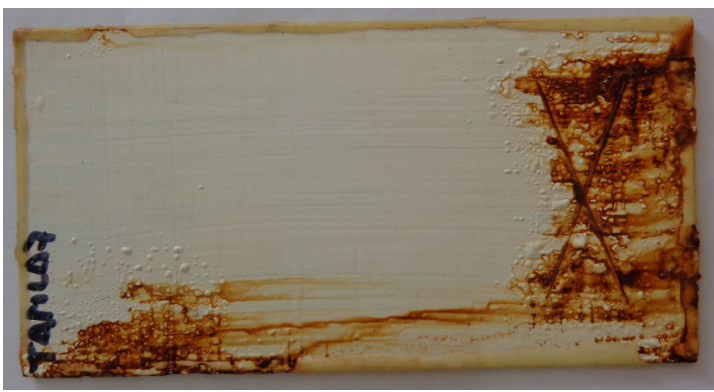

(a) Exposed panel

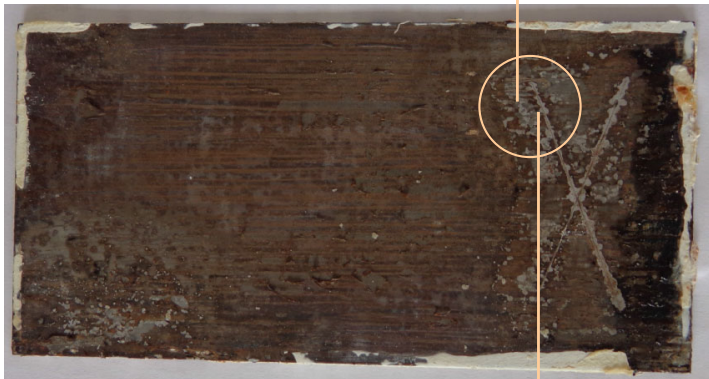

(b) Unpainted panel

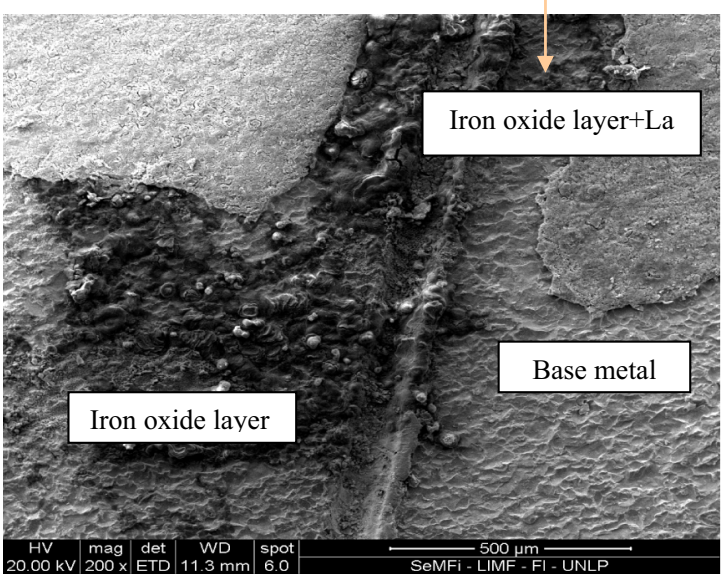

(e) $200 \mathrm{X}$

Fig. 13 SEM micrographs of the steel surface coated with the paint system containing the lanthanum "tannate" primer exposed to the salt spray test for 25 days. (a) Exposed panel, (b) unpainted panel; after removal of the alkyd paints (c and d) far from the crosscut, (e) adjacent to the crosscut 


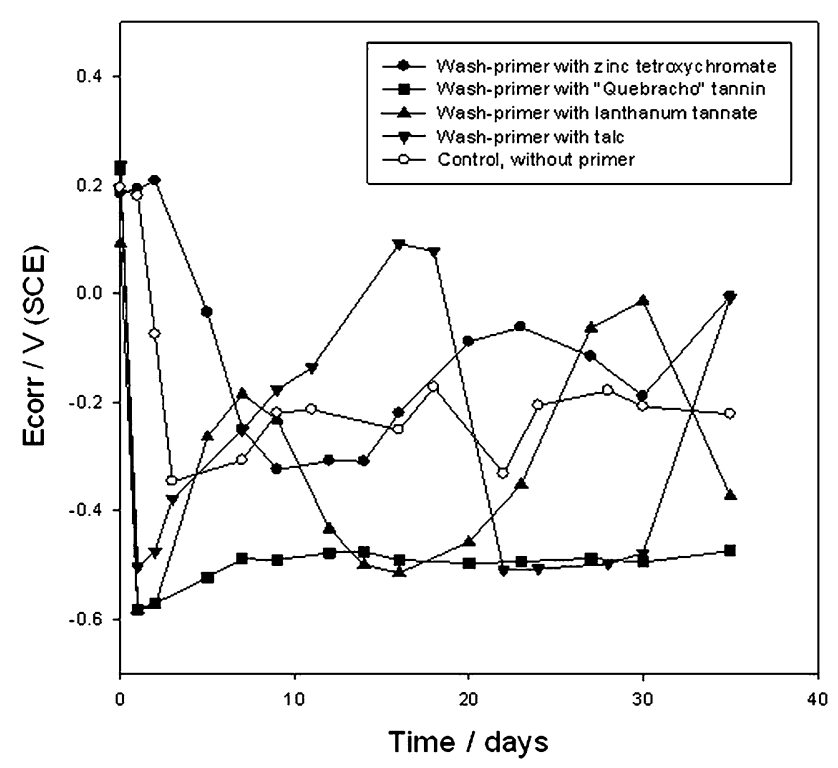

Fig. 14 Corrosion potential of primed panels coated with the alkyd system, as a function of time, in $\mathrm{NaCl} 0.5 \mathrm{M}$

containing the primers with ZTC and LT which showed a capacitive behavior during the first days of immersion. Impedance data could be fitted using the two equivalent circuits depicted in Fig. 16 which were previously discussed in the literature (Ref 82,83 ). The first one, with only one time constant, describes the film properties, and the other was employed to fit experimental data once the corrosion process was started. The point of view adopted in this paper was that of Amirudin and Thierry in the sense that the exact number of time constants is better determined from the fitting of experimental data by dedicated software (Ref 84$)$.
All tested paint systems exhibited a barrier to ion diffusion as it could be deduced from the values of the pore resistance $(\mathrm{Rm})$ in Fig. 17. These values were higher than $1.0 \times 10^{6} \Omega \mathrm{cm}^{2}$, the threshold value suggested in the literature (Ref 77, 78). Initially, during the first two days of immersion, the pore resistance of the inhibited primers was higher than $1.0 \times 10^{9} \Omega \mathrm{cm}^{2}$, indicating full barrier effect; the exception was the system with the primer containing QT. The primer with talc also showed this effect, but the resistance descended after the first day of immersion. During the first month of immersion the pore resistance fluctuated between $2.0 \times 10^{6}$ and $7.0 \times 10^{7} \Omega \mathrm{cm}^{2}$. Taking into account the low ionic resistance of the primers (Fig. 5), it is clear that the alkyd system was responsible for the high ionic resistance values measured. However, the ionic resistance of the primed panels was, as a general rule, higher than the control, particularly during the first 2 weeks of immersion. The primer containing ZTC caused the ionic resistance to be higher than the control during 12 days of immersion, while this period increased to 17 days in the case of the LT primer. The primer formulated with talc showed a higher pore resistance than the control during 28 days; maybe due to the accumulation of corrosion products in the primer film. Finally, the pore resistance of the panel coated with the primer containing LT showed full barrier protection at the end of the test period. The values of the film capacitance $(\mathrm{Cm})$ for the systems containing a wash-primer were lower than that of the control paint system. This fact showed that the wash-primers contributed to improve the integrity of the paint film. Differences among the different wash-primers were not significant (Fig. 17).

The charge transfer resistance (R1) was higher in those systems containing a primer; so, the presence of a wash-primer increased the resistance of the coated metal to corrosion (Fig. 18). It is also interesting to note that the corrosion process was delayed in the primed systems pigmented with ZTC and LT; the second time constant appeared later (1-5 days) with 

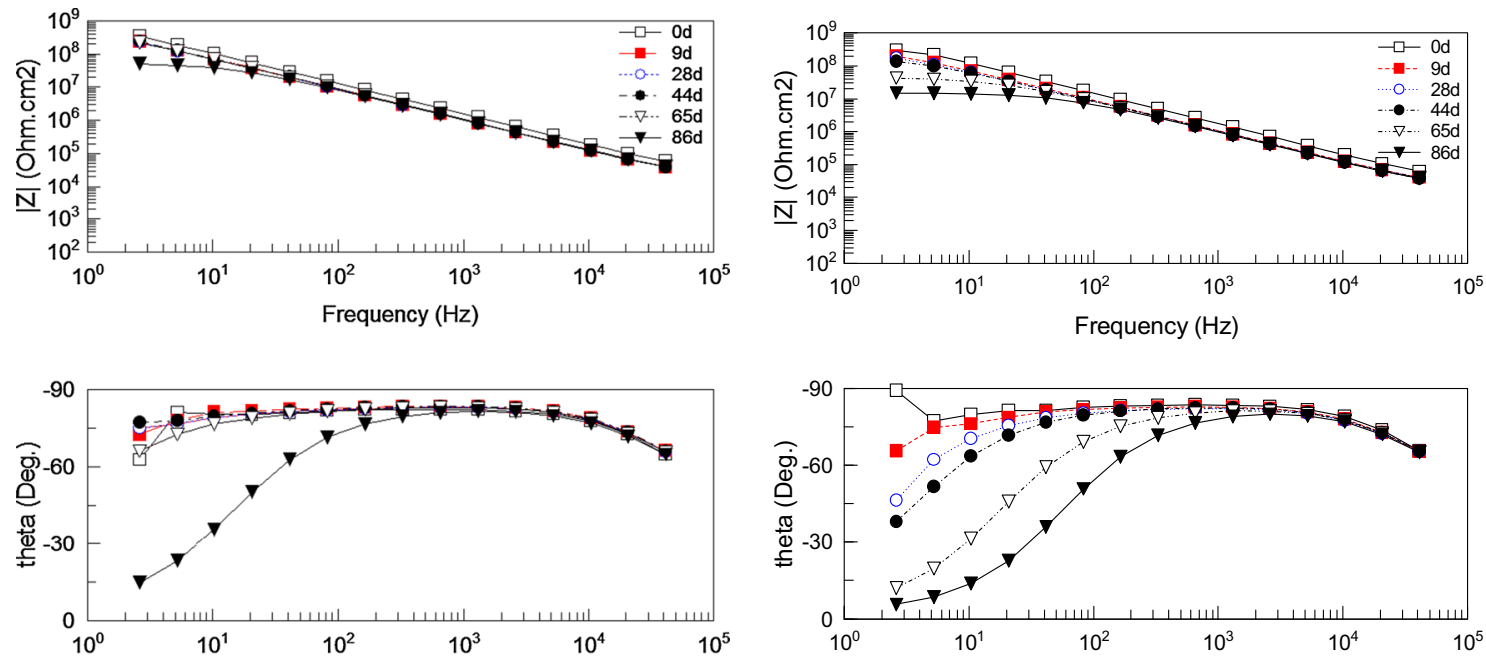

(a)

Frequency $(\mathrm{Hz})$

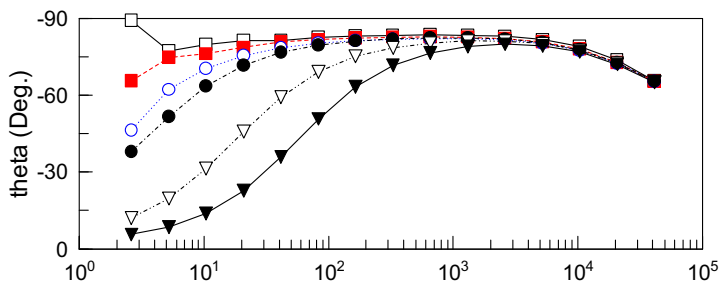

(b)

Frequency $(\mathrm{Hz})$
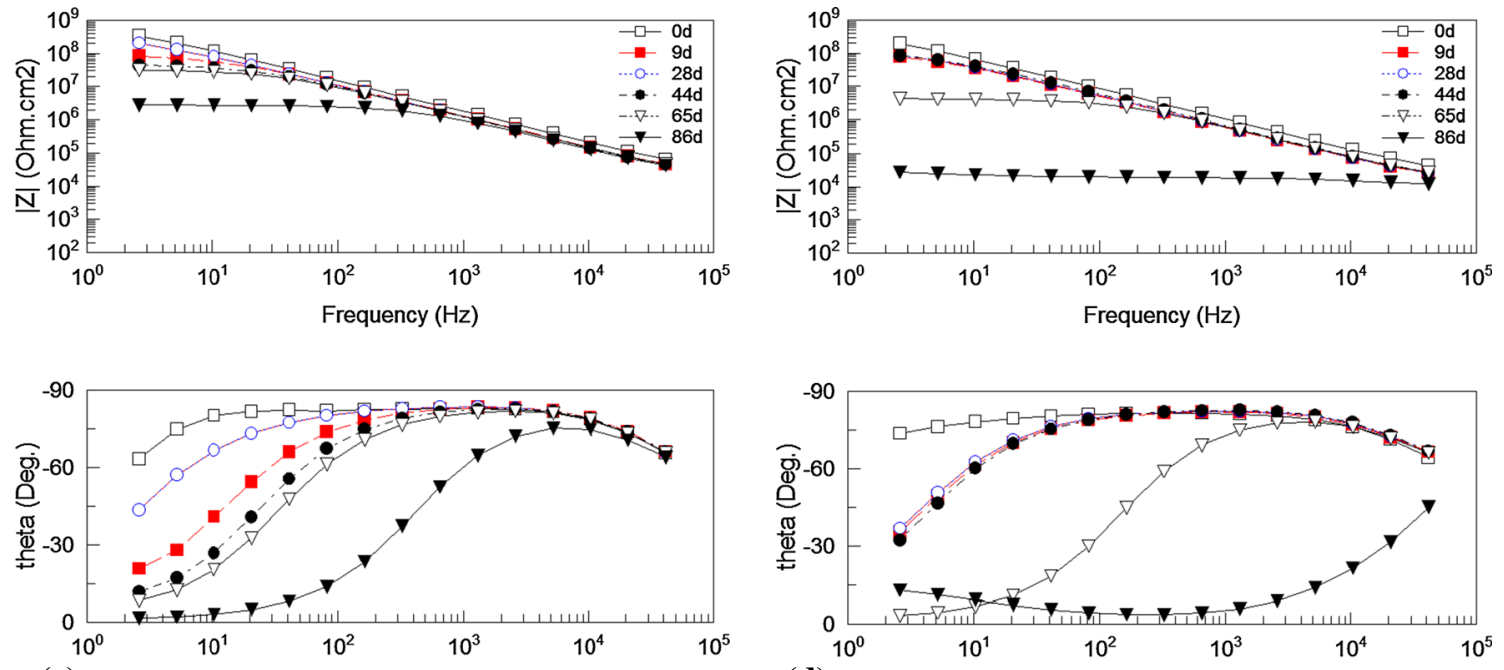

(c)

Frequency $(\mathrm{Hz})$

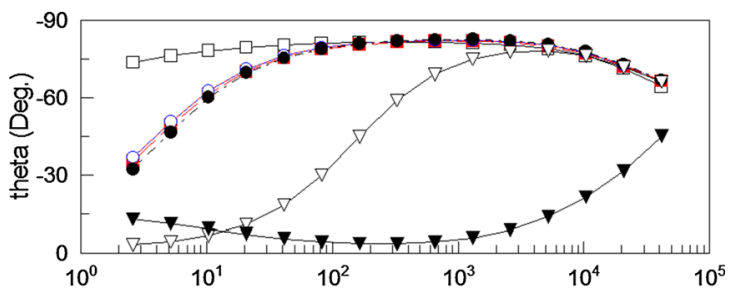

(d)

Frequency $(\mathrm{Hz})$
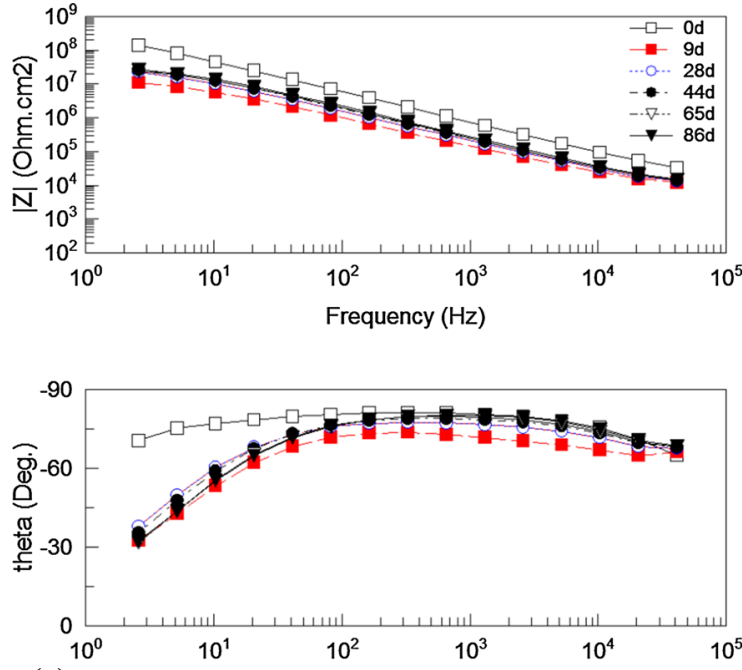

(e)

Frequency $(\mathrm{Hz})$

Fig. 15 Bode's plots of different painting schemes. (a) zinc tetroxychromate primer, (b) "quebracho" tannin primer, (c) lanthanum "tannate" primer, (d) talc primer, (e) without primer 


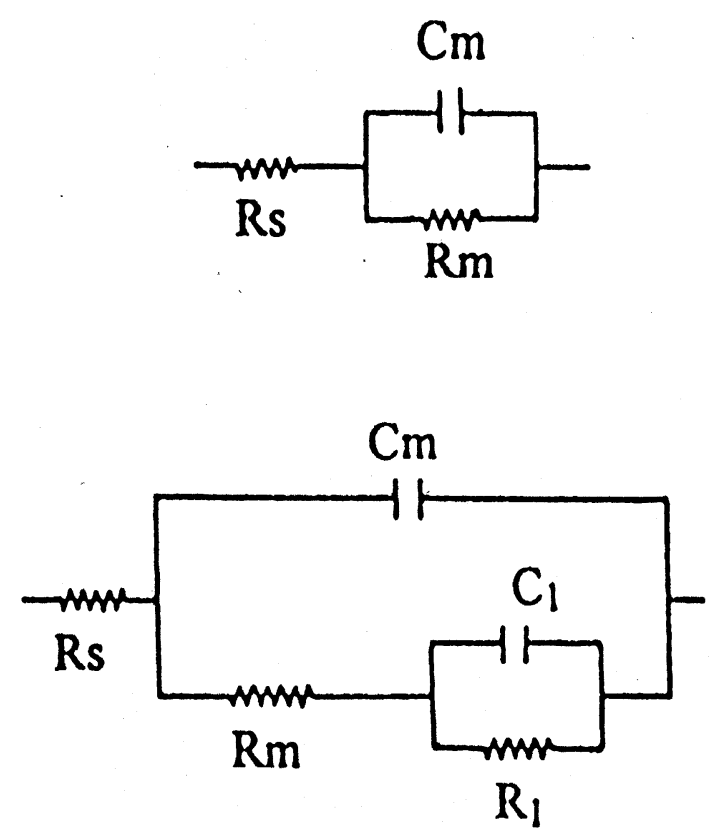

Fig. 16 Equivalent circuits to fit EIS experimental data

respect to the control. The highest value of the $\mathrm{R} 1$ was measured for the primer containing ZTC. R1 for the primer with LT was lower than that of the primer with ZTC and similar to the values obtained for the primer with QT at the end of the test period. The lowest value of R1 was detected for the primer with talc; however, the differences were not so high. This fact points out that the primer with talc could be also useful for steel temporary protection. The capacitance of the double layer $(\mathrm{C} 1)$ was lower for the inhibited primer, thus revealing that the active surface area in the primed systems was smaller.

\section{Conclusions}

1. Lanthanum "tannate" (LT) could be precipitated by mixing a tannin suspension and a lanthanum nitrate solution in the following proportion: $3 \mathrm{~g}$ of tannin: $3.0 \mathrm{mmol}$ of La(III).

2. The as-prepared LT inhibited steel corrosion rate in chloride media. Lanthanum "tannate" displaced steel corro-
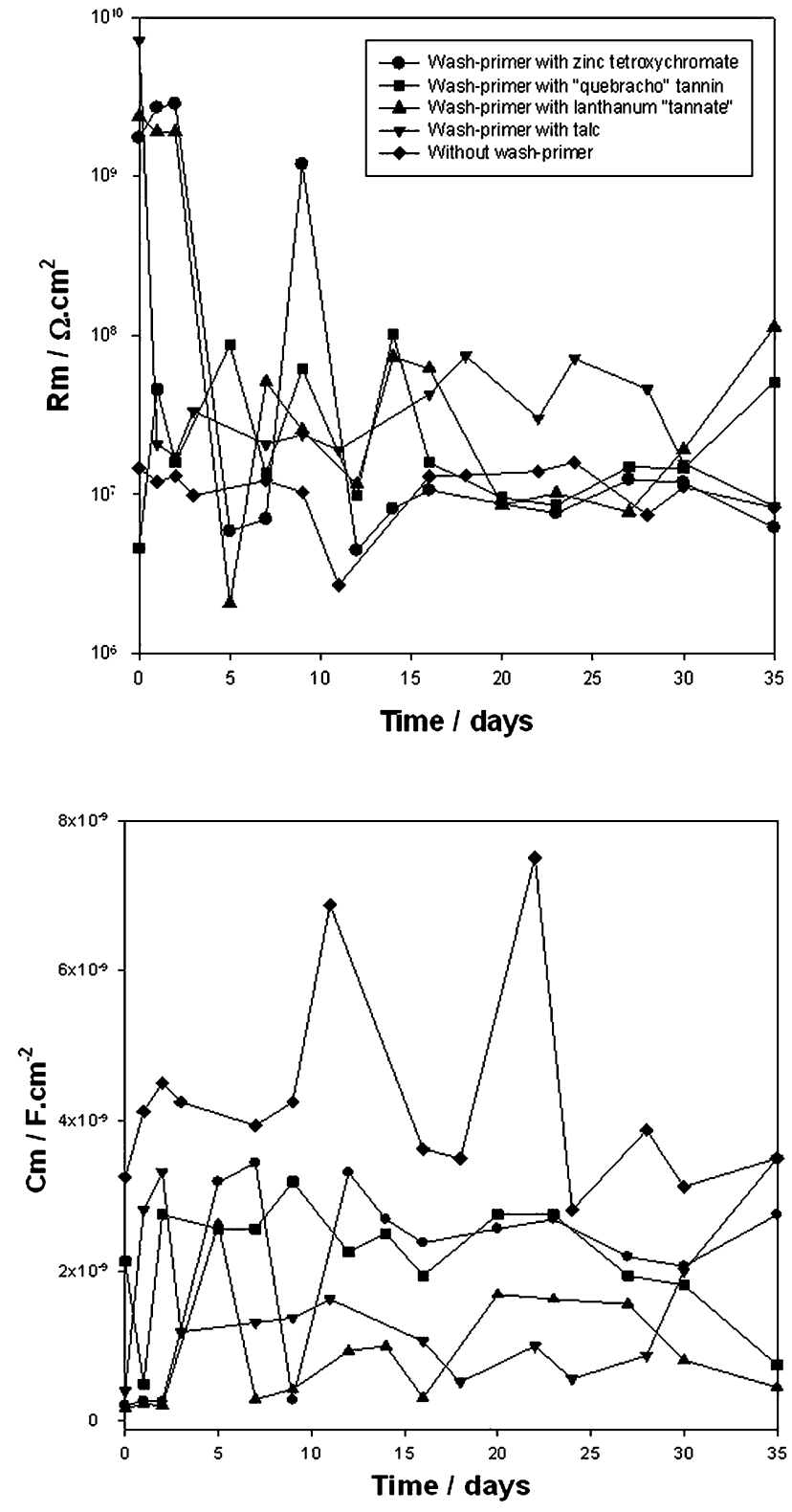

Fig. 17 Pore resistance $(\mathrm{Rm})$ and film capacitance $(\mathrm{Cm})$ of primed panels coated with the alkyd system, as a function of time, in $\mathrm{NaCl}$ $0.5 \mathrm{M}$ 

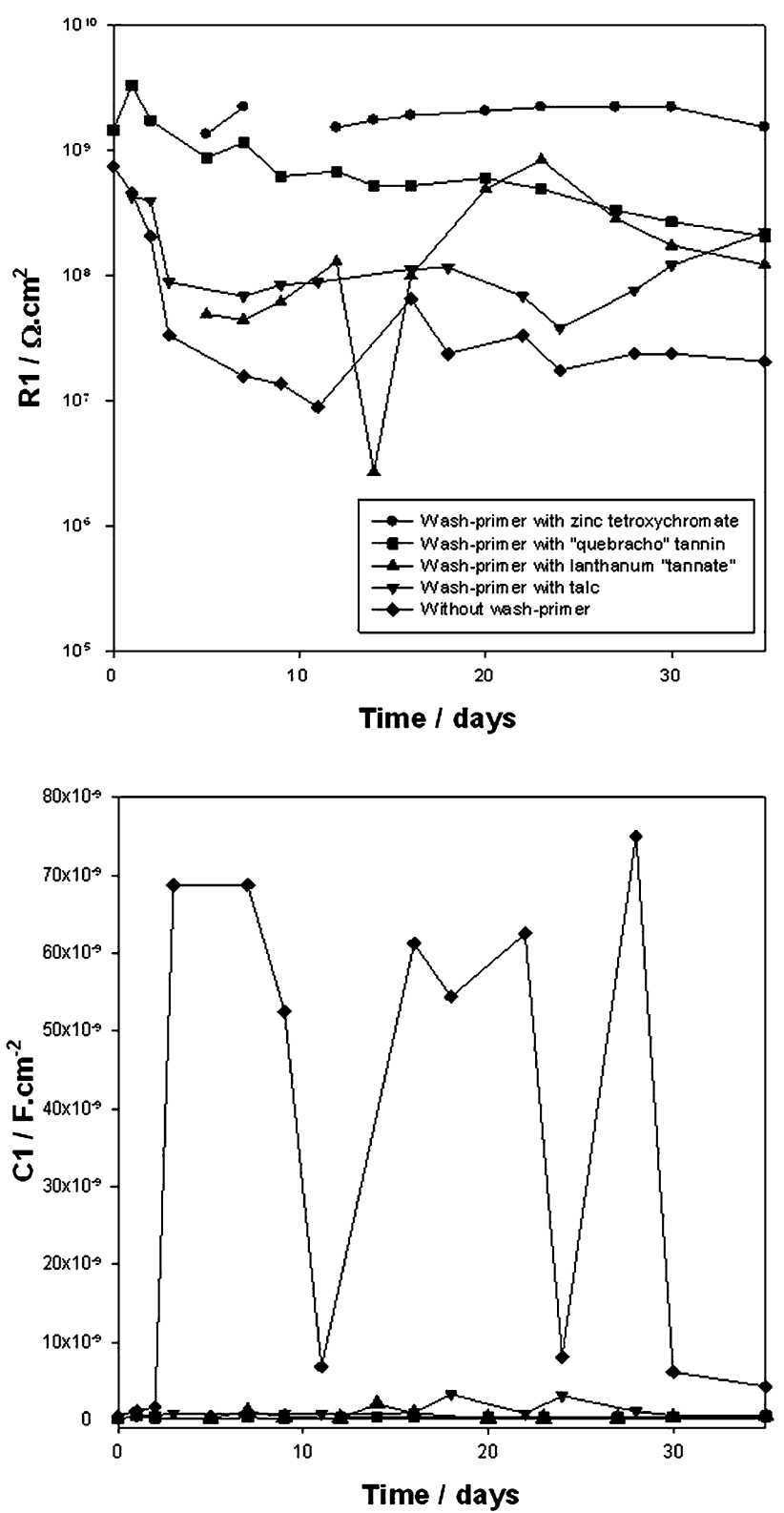

Fig. 18 Charge transfer resistance (R1) and double layer capacitance $(\mathrm{C} 1)$ of primed panels coated with the alkyd system, as a function of time, in $\mathrm{NaCl} 0.5 \mathrm{M}$

sion potential to more positive values. Its anticorrosion efficiency was $\sim 94 \%$.

3. It was possible to formulate a wash-primer replacing zinc tetroxychromate (ZTC) by Lanthanum "tannate".

4. The primer formulated with LT inhibited steel corrosion rate, but the primer formulated with ZTC had a slightly better anticorrosion performance.

5. The primer formulated with ZTC incorporated into a complete alkyd paint system performed slightly better than that with LT in the salt spray test.

6. Results from the electrochemical assessment revealed that the presence of a wash-primer in the paint system delayed the onset of the corrosion process. The primers formulated with ZTC and the one containing LT had a similar anticorrosion behavior. The charge transfer resistance of the former was slightly higher.

\section{Acknowledgments}

The authors thank to Consejo Nacional de Investigaciones Científicas y Técnicas (CONICET), Universidad Nacional de La Plata (UNLP) and Comisión de Investigaciones Científicas of Buenos Aires (CICPBA), for the economical support to do this research.

\section{References}

1. BS 1133 Section 6:1966-Packaging Code. Temporary Protection of Metal Surfaces Against Corrosion (During Transport and Storage)

2. Guide to Temporary Corrosion Protectives. National Physical Laboratory (NPL), National Corrosion Service, UK, 2003, 1-16. http://www.npl.co.uk/upload/pdf/temporary_corrosion_protectives.pdf

3. D.R. Gabe and D.W. Hopkins, Principles of Metal Surface Treatment and Protection, 2nd ed., Elsevier, Oxford, 1978, p 116-129

4. L.L. Shreir, Corrosion Vol. II, Corrosion Control. (Newnes-Butterworth, London, 1976), Chapter 16

5. S. Paul, Surface Coatings: Science and Technology, 2nd ed., Wiley, Chichester, 1996, p 477-512

6. J.M. Waldie, Surface Coatings, Vol II: Paints and their Applications, OCCA, Oxford, 1974

7. E. Groshart, Preparation of Nonferrous Metals for Painting, Met. Finish., 2010, 108(11-12), p 64-68

8. H. Rosenbloom, Chemistry of Wash-Primers, Ind. Eng. Chem., 1953, 45, $\mathrm{p}$ 2561-2568

9. S. Wilbur, H. Abadin, M. Fay, D. Yu, and M.S. Tencza, Toxicological Profile for Chromium, Agency for Toxic Substances and Disease Registry (US), Atlanta, 2012

10. L. Chromy and E. Kaminska, Non-Toxic Anticorrosion Pigments, Prog. Org. Coat., 1990, 18, p 319-324

11. M.J. Prior and M. Cohen, The Inhibition of the Corrosion of Iron by Some Anodic Inhibitors, J. Electrochem. Soc., 1953, 100, p 203-215

12. M. Gharagozlou, B. Ramezanzadeh, and Z. Baradaran, Synthesize and Characterization of a Novel Anticorrosive Cobalt Ferrite Nanoparticles Dispersed in Silica Matrix $\left(\mathrm{CoFe}_{2} \mathrm{O}_{4}-\mathrm{SiO}_{2}\right)$ to Improve the Corrosion Protection Performance of Epoxy Coating, Appl. Surf. Sci., 2016, 377, p $86-98$

13. C. Deyá, G. Blustein, B. del Amo, and R. Romagnoli, Evaluation of Eco-Friendly Anticorrosive Pigments for Paints in Service Conditions, Prog. Org. Coat., 2010, 69(1), p 1-6

14. N.M. Ahmed, H.T.M. Abdel-Fatah, and E.A. Youssef, Corrosion Studies on Tailored Zn Co Aluminate/Kaolin Core-Shell Pigments in Alkyd Based Paints, Prog. Org. Coat., 2012, 73(1), p 76-87

15. M.R. Bagherzadeh, M. Ghasemi, F. Mahdavi, and H. Shariatpanahi, Investigation on Anticorrosion Performance of Nano and Micro Polyaniline in New Water-Based Epoxy Coating, Prog. Org. Coat., 2011, 72(3), p 348-352

16. N. Elhalawany, M.M. Saleeb, and M.K. Zahran, Novel Anticorrosive Emulsion-Type Paints Containing Organic/Inorganic Nanohybrid Particles, Prog. Org. Coat., 2014, 77(2), p 548-556

17. E. Shchukina, D. Shchukin, and D. Grigoriev, Effect of InhibitorLoaded Halloysites and Mesoporous Silica Nanocontainers on Corrosion Protection of Powder Coatings, Prog. Org. Coat., In Press, Corrected Proof, Available online 20 May 2016

18. J.M. Falcón, F.F. Batista, and I.V. Aoki, Encapsulation of Dodecylamine Corrosion Inhibitor on Silica Nanoparticles, Electrochim. Acta, 2014, 124(1), p 109-118

19. D. Li, F. Wang, X. Yu, J. Wang, Q. Liu, P. Yang, Y. He, Y. Wang, and M. Zhang, Anticorrosion Organic Coating with Layered Double Hydroxide Loaded with Corrosion Inhibitor of Tungstate, Prog. Org. Coat., 2011, 71(3), p 302-309

20. D.N. Thuy, H.T.T. Xuan, A. Nicolay, Y. Paint, and M.-G. Olivier, Corrosion Protection of Carbon Steel by Solvent Free Epoxy Coating Containing Hydrotalcites Intercalated with Different Organic Corrosion Inhibitors, Prog. Org. Coat., 2016, 101, p 331-341

21. A. Yabuki, A. Kawashima, and I.W. Fathona, Self-healing Polymer Coatings with Cellulose Nanofibers Served as Pathways for the Release of a Corrosion Inhibitor, Corr. Sci., 2014, 85, p 141-146

22. S.H. Sonawane, B.A. Bhanvase, A.A. Jamali, S.K. Dubey, S.S. Kale, D.V. Pinjari, R.D. Kulkarni, P.R. Gogate, and A.B. Pandit, Improved Active Anticorrosion Coatings Using Layer-by-Layer Assembled $\mathrm{ZnO}$ 
Nanocontainers with Benzotriazole, Chem. Eng. J., 2012, 189-190, p 464-472

23. B.H. Cruz, J.M. Díaz Cruz, C. Ariño, and M. Esteban, Heavy Metal Binding by Tannic Acid, A Voltammetric Study, Electroanalysis, 2000, 12, p 1130-1137

24. T.K. Ross and R.A. Francis, The Treatment of Rusted Steel with Mimosa Tannin, Corros. Sci., 1978, 18, p 351-361

25. V.F. Vetere and R. Romagnoli, Chemical and Electrochemical Assessment of Tannins and Aqueous Primers Containing Tannins, Surf. Coat. Int., 1998, 81, p 385-391

26. A. Jaén, J. De Obaldía, and M.V. Rodríguez, Application of Mössbauer Spectroscopy to the Study of Tannins Inhibition of Iron and Steel Corrosion, Hyperfine Interact., 2011, 202, p 25-38

27. I.B. Obot and A. Madhankumar, Enhanced Corrosion Inhibition Effect of Tannic Acid in the Presence of Gallic Acid at Mild Steel/HCl Acid Solution Interface, J. Ind. Eng. Chem., 2015, 25, p 105-111

28. K. Chang and T. Viswanathan, Electrochemical Studies of Tannin for Corrosion Protection of Steel, Polym. Mater. Sci. Eng., 2001, 84, p 1055-1060

29. S. Martinez and I. Stern, Thermodynamic Characterization of Metal Dissolution and Inhibitor Adsorption Processes in the Steel/Mimosa Tannin/Sulfuric Acid, Appl. Surf. Sci., 2002, 199, p 83-89

30. B. Qian, M. Hou, and B. Zheng, The Inhibition Effect of Tannic Acid on Mild Steel Corrosion in Seawater Wet/Dry Cyclic Conditions, Corr. Sci., 2013, 72, p 1-9

31. S. Martinez and I. Štern, Inhibitory Mechanism of Low-Carbon Steel Corrosion by Mimosa Tannin in Sulphuric Acid Solutions, J. Appl. Electrochem., 2001, 31, p 973-978

32. S. Martinez and I. Štern, Ferric-Tannate Formation and Anticorrosion Properties of Mimosa Tannin in Acid Solutions, Chem. Biochem. Eng. Q., 1999, 13, p 191-199

33. S. Martinez, Inhibitory Mechanism of Mimosa Tannin Using Molecular Modeling and Substitutional Adsorption Isotherms, Mater. Chem. Phys., 2002, 77, p 97-102

34. K. Tan and M.J. Kassim, A Correlation Study on the Phenolic Profiles and Corrosion Inhibition Properties of Mangrove Tannins (Rhizophora Apiculata) as Affected by Extraction Solvents, Corr. Sci., 2011, 53(2), p 569-574

35. H. Gerengi, K. Schaefer, and H.I. Sahin, Corrosion-Inhibiting Effect of Mimosa Extract on Brass-MM55 Corrosion in $0.5 \mathrm{M} \mathrm{H}_{2} \mathrm{SO}_{4}$ Acidic Media, J. Ind. Eng. Chem., 2012, 18(6), p 2204-2210

36. O.R. Pardini, J.I. Amalvy, A.R. Di Sarli, R. Romagnoli, and V.F. Vetere, Formulation and Testing of a Water-Borne Primer Containing Chestnut Tannin, J. Coat. Tech., 2001, 73, p 99-106

37. S. Hornus Sack, R. Romagnoli, V.F. Vetere, C.I. Elsner, O. Pardini, J.I. Almalvy, and A.R. Di Sarli, Evaluation of Steel/Primer Based on Chestnut Tannin/Paint Film Systems by EIS, J. Coat. Tech., 2002, 74, p 63-69

38. G. Matamala, W. Smeltzer, and G. Droguett, Comparison of Steel Anticorrosion Protection Formulated with Natural Tannins Extracted from Acacia and from Pine Bark, Corr. Sci., 1994, 42, p 1351-1362

39. A.A. Rahim, E. Rocca, J. Steinmetz, M.J. Kassim, R. Adnan, and M. Sani Ibrahim, Mangrove Tannins and Their Flavanoid Monomers as Alternative Steel Corrosion Inhibitors in Acidic Medium, Corr. Sci., 2007, 49, p 402-417

40. A.A. Rahim, E. Rocca, J. Steinmetz, and M.J. Kassim, Inhibitive Action of Mangrove Tannins and Phosphoric Acid on Pre-rusted Steel via Electrochemical Methods, Corr. Sci., 2008, 50, p 1546-1550

41. J. Aguilar López, J.C. Jaén Jiménez, A.S. Vargas Abarca, P. Jiménez Bonilla, I. Vega Guzmán, J. Herrera Núñez, H. Borbón Alpízar, and R.M. Soto Fallas, Extracción y evaluación de taninos condensados a partir de la corteza de once especies maderables de Costa Rica, Tecnología en Marcha, 2012, 25, p 15-22

42. N. Rhazi, H. Hannache, M. Oumam, A. Sesbou, B. Charrier, A. Pizzi, and F. Charrier-El Bouhtoury, Green Extraction Process of Tannins Obtained from Moroccan Acacia Mollissima Barks by Microwave: Modeling and Optimization of the Process Using the Response Surface Methodology RSM, Arabian J. Chem., In Press, Corrected Proof, Available online 21 May 2015

43. M.I. González and A. Abreu, Utilización de las Curvas de Polarización Anódica Para Determinar la Efectividad de un Convertidor de Óxidos, Revista de Ciencias Químicas de Cuba, 1984, 15, p 315-317

44. M. Morcillo, M. García, J.R. Gancedo, and F.S. Estudio del comportamiento de diferentes productos convertidores de óxido (Study of the behavior of different products to convert rust), II Congreso Iberoamericano de Corrosión y Protección, 09-14 Nov 1986, Maracfaibo, Venezuela, Memorias, 221

45. A.T. Ochoa, N. Polianskaya and Z.E. Álvarez, Estudio comparativo de primarios modificadores de herrumbre, (Comparative study of primers to modify rust), II Congreso Iberoamericano de Corrosión $y$ Protección, 09-14 November 1986, Maracaibo, Venezuela, Memorias, 259

46. G. Joseph and R. Vallejos, Determinación mediante espectroscopía Mössbauer de la formación de $\mathrm{Fe}_{3} \mathrm{O}_{4}$ en una superficie de acero cubierta con pintura anticorrosiva estabilizadora de óxido, Rev. Iberoamericana de Corrosión y Protección., 1988, 19, p 379

47. A. Collazo, X.R. Nóvoa, C. Pérez, and B. Puga, EIS Study of the Rust Converter Effectiveness Under Different Conditions, Electrochim. Acta, 2008, 53, p 7565-7574

48. L.M. Ocampo, I.C.P. Margarit, O.R. Mattos, S.I. Córdoba-de-Torresi, and F.L. Fragata, Performance of Rust Converter Based in Phosphoric and Tannic Acids, Corr. Sci., 2004, 46, p 1515-1525

49. C.A. Giúdice, J.C. Benítez, and M.L. Tonello, Tin Tannates and Iron Tannates in Corrosion-Inhibiting Coatings, Pitt. Ver. Eur., 1998, 74, p 23-29

50. C.A. Giúdice, J.C. Benítez, and M.L. Tonello, Testing the Use of Metallic Tannates as Inhibitors in Anticorrosion Coatings, Prot. Coat. Eur., 1999, 4, p 13-19

51. C.A. Giúdice, J.C. Benítez, and M.L. Tonello, Chromium (VI) Tannates as Inhibitors in Anticorrosion Coatings: Influence of the Metal Content, Eur. Coat. J., 2000, 6, p 48-54

52. A. Hadzich, S. Flores, R. Romagnoli, and J. Caprari, Estudios de tanatos de cinc preparados con polvo de tara (Caesalpinia spinosa) como pigmentos anticorrosivos en pinturas alquídicas y formulaciones de wash primers, to be held at X Latincorr 2016, México 25-28 October

53. S. Flores, J. Caprari, L. Figueroa, and R. Romagnoli, Inhibición de la corrosión del acero por "tanatos" metálicos. Estudio comparativo de pinturas epoxídicas formuladas con tanatos metálicos en ensayos de corrosión acelerada, Intercorr 2014, Fortaleza, Brasil. 19-23 may 2014. Trabajos en CD, INTERCOORR2014_119

54. B. Davó and J.J. de Damborenea, Use of Rare Earth Salts as Electrochemical Corrosion Inhibitors for an Al-Li-Cu (8090) Alloy in $3.56 \% \mathrm{NaCl}$, Electrochim. Acta, 2004, 49, p 4957-4965

55. M. Forsyth, K. Wilson, T. Behrsing, C. Forsyth, G.B. Deacon, and A. Phanasgoankar, Effectiveness of Rare-Earth Metal Compounds as Corrosion Inhibitors for Steel, Corrosion, 2002, 58(11), p 953-960

56. Y. Zhu, J. Zhuang, Y. Yu, and X. Zeng, Research on anti-corrosion property of rare earth inhibitor for X70 steel, J. Rare Earths, 2013, 31(7), p 734-740

57. C. Motte, M. Poelman, A. Roobroeck, M. Fedel, F. Deflorian, and M.G. Olivier, Improvement of Corrosion Protection Offered to Galvanized Steel by Incorporation of Lanthanide Modified Nanoclays in Silane Layer, Prog. Org. Coat., 2012, 74(2), p 326-333

58. A. Santana, I. Pepe, E. Jimenez-Pique, S. Pellice, I. Milošev, and S. Ceré, Corrosion Protection of Carbon Steel by Silica-Based Hybrid Coatings Containing Cerium Salts: Effect of Silica Nanoparticle Content, Surf. Coat. Tech., 2015, 265(15), p 106-116

59. K. Juchi and Y. Huang, Effect of Rare Earth on the Coating-Forming and Mechanism of Phosphatization, J. Rare Earths, 2010, 28, p 132135

60. M.F. Montemor, W. Trabelsi, M. Zheludevich, and M.G.S. Ferreira, Modification of Bis-silane Solutions with Rare-Earth Cations for Improved Corrosion Protection of Galvanized Steel Substrates, Prog. Org. Coat., 2006, 57, p 67-77

61. P.B. Raja and M. Golalakrishnan Sethuraman, Natural Products as Corrosion Inhibitor for Metals in Corrosive Media. A Review, Mater. Lett., 2008, 62, p 113-116

62. N. Bellotti, C. Deya, B. del Amo, and R. Romagnoli, Antifouling Paints with Zinc "Tannate", Ind. Eng. Chem. Res., 2010, 49, p 33863390

63. S.B. Erdemoglu and S. Gucer, Selective Determination of Aluminium Bound with tannin in Tea Infusion, Anal. Sci., 2005, 21(8), p 10051008

64. E.C. Ferreira, A.R.A. Nogueira, G.B. Souza, and L.A.R. Batista, Effect of Drying Method and Length of Storage on Tannin and Total Phenol Concentrations in Pigeon Pea Seeds, Food Chem., 2004, 86(1), p 1723 
65. M. Stern and A.L. Geary, Electrochemical Polarization: I. A Theoretical Analysis of the Shape of Polarization Curves, J. Electrochem. Soc., 1957, 104, p 56-63

66. S. Wolynec, Técnicas eletroquímicas en corroção, Universidade de São Paulo, San Pablo, 2003, p 73

67. SSPC STANDARDS-SSPC-PAINT 27, Basic Zinc Chromate-Vinyl Butyral Wash Primer

68. Butvar. Polyvinyl Butiral Resin. Properties and Uses. Publication No 2008084E, Coatings Performance Materials by SOLUTIA, http://www.butvar.com

69. C. Hare, Protective Coatings: Fundamentals of Chemistry and composition, Technology Publishing Company, Pennsylvania, 1994

70. J. Koleske, Paint and Coating Testing Manual, ASTM, Pennsylvania, 1995

71. G.W. Walter, A Review of Impedance Plot Methods Used for Corrosion Performance Analysis of Painted Metals, Corr. Sci., 1986, 26, p 681-703

72. B. del Amo, R. Romagnoli, and V.F. Vetere, Study of the Anticorrosive Properties of Zinc Phosphate and Zinc Molybdophosphate in Alkyd Paints, Corros. Rev., 1996, 14, p 121-131

73. A. Gerhard and A. Bittner, Second Generation Phosphate AntiCorrosive Pigments. Formulating Rules for Full Replacement of New Anti-Corrosive Pigments, J. Coat. Technol., 1986, 58, p 59-65

74. A. Bittner, Advanced Phosphate Anticorrosion Pigments for Compliant Primers, J. Coat. Technol., 1989, 61, p 111-118

75. B.A. Boukamp, Report CT88/265/128, CT89/214/128, University of Twente, Enschede, 1989
76. T. Szauer, Electrical and Electrochemical Resistance for Protective non Metallic Coatings, Prog. Org. Coat., 1982, 10, p 157-170

77. H. Leidheiser, Electrical and Electrochemical Measurements as Predictors of Corrosion at the Metal-Organic Coatings Interface, Prog. Org. Coat., 1979, 7, p 79-104

78. Z. Szklarska-Smialowska and J. Mankowsky, Cathodic Inhibition of the Corrosion of Mild Steel in Phosphate, Tungstate, Arsenate and Silicate Solutions Containing $\mathrm{Ca}^{2+}$ Ions, Br. Corros. J., 1969, 4, p 271275

79. M. Kendig and J. Scully, Basic Aspects of Electrochemical Impedance Application for the Life Prediction of Organic Coatings on Metals, Corrosion, 1990, 46, p 22-29

80. T. Szauer, Impedance Measurements for the Evaluation of Protective Nonmetallic Coatings, Prog. Org. Coat., 1982, 10, p 171-183

81. S. Skale, V. Doleček, and M. Slemnik, Electrochemical Impedance Studies of Corrosion Protected Surfaces Covered with Epoxy Polyamide Coating System, Prog. Org. Coat., 2008, 62, p 387-392

82. C. Haynes and R. Baboian, Electromechanical Impedance Tests for Protective Coatings, ASTM, Philadelphia, 1985

83. O. Ferraz, E. Cavalcanti, and A.R. Di Sarli, The Characterization of Protective Properties for Some Naval Steel/Polymeric Coatings/ $3 \% \mathrm{NaCl}$ Solution Systems by EIS and Visual Assessment, Corr. Sci., 1995,37, p $1267-1280$

84. A. Amirudin and D. Thierry, Application of Electrochemical Impedance Spectroscopy to Study Efficiency of Anticorrosion Pigments in Epoxy-Polyamide Resin, Br. Corr. J., 1995, 30, p 128-134 